\title{
Can Mima-like Mounds be Vertisol relics (Far North Region of Cameroon, Chad Basin)?
}

Nathalie Diaz ${ }^{1 *}$, Fabienne Dietrich ${ }^{1}$, Guillaume Cailleau${ }^{1}$, David Sebag², Benjamin Ngounou Ngatcha ${ }^{3}$ and Eric P. Verrecchia ${ }^{1}$

"Corresponding author: nathalie.diaz@unil.ch

1: Institute of Earth Surface Dynamics, Faculty of Geosciences and the Environment, University of Lausanne, Geopolis, 1015 Lausanne, Switzerland

2: Laboratoire HydroSciences Montpellier, UMR CNRS/IRD 5569, University of Ngaoundéré, Cameroon, and Laboratoire de Morphodynamique Continentale et Côtière, UMR 6143 CNRS, University of Rouen, 76821 Mont Saint Aignan Cedex, France

3: University of Ngaoundéré, Faculty of Sciences, Department of Earth Sciences, BP 454 Ngaoundéré, Cameroon 


\section{Abstract}

Non-anthropogenic earth mounds, defined as mima-like mounds in this study, have recently been observed in non-carbonate watersheds along the Sudano-Sahelian belt in the Chad Basin. In the Diamare piedmont (northern Cameroon) they are particularly well developed within stream networks. In less eroded areas, they occur as whaleback, flattened morphologies, or even as buried features. All these shapes are composed of clay-rich sediment associated with high proportions of secondary carbonate nodules and Fe-Mn micro-nodules. Their soil structure is prismatic to massive and vertical cracks are observed locally. Grain-size distributions emphasize the clay-rich nature of the sediment, with average clay contents of $32 \% \pm 12.8 \%$ $(n=186)$, which is significantly higher than the clay content in the adjacent sediments in the landscape (mean $=10 \% \pm 4 \%, n=21$ ). Moreover, high proportions of smectite characterize the soil, with average contents of $34 \pm 7 \%(n=25)$. At the micro-scale, the groundmass has a cross-striated b-fabric, with embedded smooth subangular quartz and feldspar grains of the silt-size fraction. All the characteristics point to altered vertic properties in the clay-rich sediment composing the mima-like mounds. Mima-like mounds are thus interpreted as degraded Vertisols. Compared to presentday Vertisols occurring in the piedmont, mima-like mounds are located upstream. It is thus proposed that the Vertisol areas were more extensive during a former and wetter period than the present-day. Subsequent changing climatic conditions increased erosion, revealing the gilgai micro-relief by preferential erosion in microlows rather than in micro-highs. Mima-like mounds of the Chad Basin might thus result from pedogenesis combined with later erosion. These local processes can be inherited from regional climatic variations during the Late Pleistocene-Holocene and likely be related to the African Humid Period.

Keywords: Erosion; Vertisol genesis; Gilgai; Late Pleistocene-Holocene 


\section{Introduction}

Non-anthropogenic earth mounds occur in many parts of the world and the questions related to their origin make them exciting features (Cramer et al., 2012). The debate is generally centred upon the discussion of their abiotic or biotic origin. For example, earth mounds observed in South Africa (locally termed heuweltjies; Moore and Picker, 1991; Francis et al., 2012) and Brazil (Funch, 2015) are attributed to termite activity, but others provide some evidence they can result from differential erosion (Cramer et al., 2012). In North America, the geomyid pocket gopher may be involved in the mound (or mima mound) formation (e.g. Cox, 1984), but the debate on their real capability to produce them is still open (e.g. Butler, 1995). Silva et al. (2010) proposed that erosive processes combined with vegetation patterns are the cause of earth mounds (campos de murundus) observed in Brazil instead of resulting from termite activity. The origin of earth mounds changes from one region to another, but they have some common features, such as their regular spatial distribution or their size (Cramer et al., 2012). It was recently proposed that many of these different earth mounds, termed mima-like mounds, can be explained by the combination of erosion and/or aeolian processes with vegetation patterns (Cramer and Barger, 2014; Cramer and Midgley, 2015).

All along the Sudano-Sahelian belt, carbonate nodules have been observed in noncarbonate watersheds (Fig. 1A). In northern Cameroon (Fig. 1B), these nodules are associated with non-anthropogenic earth mounds (Fig. 2). These new features have not been studied up until now. In the Far North region of Cameroon (Chad Basin) they are frequently observed in the Diamare piedmont (Fig. 1B), and are particularly well developed within stream networks $(10 \mathrm{~m}<$ diameter $<30 \mathrm{~m}$ and height up to $1 \mathrm{~m}$ ). On Google Earth images (Fig. 1C), they are distributed in eroded areas as regularly spaced (i.e. over-dispersed) round features. They can be defined as mimalike mounds due to their size and their spatial distribution. However, vegetation patterns do not play a main role in their formation, whereas erosion processes do. Generally, mima-like mounds are associated with sparse vegetation or none at all (Fig. 2A, 3). Consequently, the conditions under which they form still remain unclear. The clay- and carbonate-rich association composing the mima-like mound sediments was already described in the Diamare piedmont (Martin, 1961; Sieffermann, 1963; Brabant and Gavaud, 1985; Morin, 2000) and also farther away in the Chad Basin (Erhart, 1954; Pias, 1962; Bocquier, 1973). Compilation of former and new field 
observations raises questions on the potential links that could exist between these multiple locations. The clay-rich sediment, enriched in carbonate nodules, can be interpreted as a layer (or multi-layer?) forming residual mima-like mounds in highly eroded areas. Regarding the soils developing from this clay-rich parent material, there are mainly Planosol, Solontez and Vertisol (Brabant and Gavaud, 1985). However, these soils are often described and mapped as degraded soils (Brabant and Gavaud, 1985). Interestingly, mima-like mounds are typically observed in these degraded zones. This is consistent with their presence in eroded areas. However, could pedogenesis have a specific role in their genesis?

The aim of this study is to characterize sedimentological and geomorphological settings of mima-like mounds from the Far North region of Cameroon and to propose a possible origin of their formation. To achieve this goal, a multiple scale approach is used compiling (1) field observations, (2) grain-size distribution and clay mineralogy data at the mound scale, and (3) thin-section observations. Roles of pedogenesis and later erosion in the formation of mima-like mounds are investigated. Two main hypotheses are proposed: (i) mima-like mounds observed in northern Cameroon are relics of Vertisols associated with a gilgai micro-relief; and (ii) they result from abiotic processes related to the succession of pedogenesis and erosion-deposition phases associated to Late Quaternary regional climatic changes. They may also be useful as paleo-environmental records for the Late Pleistocene-Holocene period in the Chad Basin.

\section{General settings}

Mima-like mounds are observed in the Diamare piedmont, spreading between the Mandara Mountains and the Yayres floodplain (Fig. 1B). The Mandara Mountains are mainly composed of granite and gneiss. Metamorphic rocks (greenschist facies), known as the green rocks of Maroua, constitute only a minor part of the massif around Maroua (Brabant and Gavaud, 1985). The transition from the Mandara Mountains to the Diamare piedmont is abrupt, with a decreasing slope from about $10 \%$ to $2 \%$, which is a typical dryland landform associated with slopes and called pediment (Morin, 2000; Goudie, 2013). The pediment infilling is heterogeneous and related to multiple pediment generations resulting from Quaternary climatic variations (Morin, 2000). From the foot of the Mandara Mountains to the Yayres floodplain, the pediment evolves from a thin cover of weathered granitic sand, to a colluvium, and 
finally to an alluvium with a grain-size distribution skewed to finer sizes. However, these settings are complicated by evidence of lateral changes, such as a clay-rich intercalation pediment, possibly of palustrine origin, and in sand lenses resulting from changes in the Mayo riverbed (Morin, 2000). The clay-rich pediment, with which carbonate nodules are often associated, outcrops along the southern bank of the Mayo Tsanaga, or is overlain by either alluvium (for example near Mora) or various generations of fersiallitic pediments starting from the foot of granitic inselbergs, as observed around Maroua and in the region of Kaele (Sieffermann, 1967; Morin, 2000). The clay-rich and carbonate-rich nature of mima-like mounds (Fig. 2) suggests that they are associated to this clay-rich pediment.

Planosol is the main type of soil found in the Diamare piedmont (Brabant and Gavaud, 1985). These soils are generally associated with Solonetz and Vertisol depending on the topography, the latter being favoured by hydromorphic conditions and developing in lower areas. The particularity of these soils is that they are often mapped as degraded soils. The local term used to emphasize soil degradation is hardé. This term characterizes soils that are very compact, with low permeability, and alkaline. These conditions make these lands sterile and only sparse vegetation can grow on them. These areas are extensive and cover 886,500 ha (Brabant and Gavaud, 1985). The other soils found in the region and not termed as hardé, are Cambisol, Ferralsol mainly located east of Kaele, and Lithosol (Brabant and Gavaud, 1985). Interestingly, the hardé characteristics listed above are also typical of mimalike mounds (Fig. 2, Table 1). The hardé areas are not automatically associated with mima-like mounds but the latter are almost always found in these specific areas (Fig. 1B).

According to the Köppen-Geiger climate classification (Peel et al., 2007), the Far North region of Cameroon belongs to the hot $\left(h=\right.$ mean annual temperature $\left.\geq 18^{\circ} \mathrm{C}\right)$, steppic $\left(S=\right.$ mean annual precipitation $\left.\geq 5^{*} P_{\text {threshold }}{ }^{1}\right)$, arid $(B)$ climate type (BSh). Summers are generally hot and there is a short well-marked wet season regulated by the monsoon. The weather station located in Salak (Fig. 1B) records an average annual rainfall of $800 \mathrm{~mm}$ and an average annual temperature of $27.6^{\circ} \mathrm{C}$ (L'Hôte, 1998). The potential evapotranspiration is $2193 \mathrm{~mm}$ and the dry season lasts for seven months with five months without any rainfall (Mahop et al., 1995). From

\footnotetext{
${ }^{1} P_{\text {threshold }}=2$ * Mean annual temperature (Peel et al., 2007)
} 
January to April, the region is also marked by dry NE trade winds, called the Harmattan (L'Hôte, 1998). Under these climatic conditions, streams are mainly ephemeral and have a WSW-ENE-flow direction through the Diamare piedmont from the Mandara Mountains to the Yayres floodplain. They belong to the endorheic Chad Basin watershed, whose hydrological limits reach the south of Maroua (Fig. 1B).

\section{Material and methods}

\subsection{Sampling}

Soil profiles are described according to the guidelines provided by the Food and Agricultural Organization of the United Nations (FAO, 2006). Depth, percentage and components of the skeleton ( $>2 \mathrm{~mm}$ ), structure, relative abundance of carbonate (tested with 10\% hydrochloric acid) and colour (determined in the field with a Munsell colour chart) are given in Table 1. Samples were collected at two main sites (Fig. 1B, stars). Trenches were opened through selected mounds. Soil profiles were described each meter along the trench. The site investigated in 2013 is located along an affluent stream of the Mayo Tsanaga (Fig. 1B). A trench $12 \mathrm{~m}$ long and $1.30 \mathrm{~m}$ deep was opened through a well-developed mima-like mound (M1, Fig. 2B, 2C). Twelve soil profiles ( $A$ to $L$, Table 1 ) were described and sampled at $5-\mathrm{cm}$ intervals in the first $10 \mathrm{~cm}$ from the top, and then every $10 \mathrm{~cm}$. A second trench, $5 \mathrm{~m}$ long and $1.30 \mathrm{~m}$ deep, was opened through a less well developed and flattened mima-like mound partially buried by a coarse-grained alluvium interfingering with the clay-rich sediment (M2, Fig. 4B). Five soil profiles ( $N$ to $R$, Table 1) were described and sampled the same way as in mound M1. A last profile ( $T$, Table 1) was described in a fersiallitic terrace ( $P$, Fig. 4A) overlying the clay-rich sediment and sampled as in mounds $M 1$ and M2. The site investigated in 2012 is located along the Mayo Tsanaga (Fig. 1B). A trench $7 \mathrm{~m}$ long and $1.30 \mathrm{~m}$ deep was opened in a mima-like mound from centre to perimeter (M3). Seven soil profiles ( $S, U$ to $A B$, Table 1) made at $1 \mathrm{~m}$ intervals were sampled every $5 \mathrm{~cm}$. This second site was investigated during a different fieldwork campaign and soil descriptions are not as complete as at the first site (Table 1, $\mathrm{nd}=\mathrm{no}$ data). All samples were dried at $45^{\circ} \mathrm{C}$ and sieved at $2 \mathrm{~mm}$ (fine earth fraction). A part of this fraction was crushed to a powder with an agate mortar (grain-size $<10$ $\mu \mathrm{m})$. Carbonate nodules were collected as well, at various depths; some of them were crushed with an agate mortar in order to have both small pieces and powders. 
Soil samples were put in metallic boxes $(8 \times 8 \times 4 \mathrm{~cm})$ to make thin sections (thickness $=30 \mu \mathrm{m})$. They were collected from mounds M1, M2, and profile $P$ at specific depths (Table 1). Samples were wedged in the best possible manner to keep the original soil structure.

\subsection{Analytical methods}

Measurement of $\mathrm{pH}_{\mathrm{H} 2 \mathrm{O}}$ was performed on the 2-mm sieved soil fraction. The soil was agitated in deionized water with a 1:25 soil to water ratio during 2 hours. The $\mathrm{pH}$ in the solution was then measured with a lab pH meter (Metrohm SA).

Grain-size distributions were performed with the laser diffraction method (Malvern ${ }^{\mathrm{TM}}$ Mastersizer 2000). Carbonate and organic fractions were removed from the dried $<2$ $\mathrm{mm}$ soil fraction, using $10 \%$ hydrochloric acid $(\mathrm{HCl})$ and $15-35 \%$ hydrogen peroxide $\left(\mathrm{H}_{2} \mathrm{O}_{2}\right)$, respectively. Finally, mineral particles were dispersed with $\mathrm{Na}$ hexametaphosphate $(40 \mathrm{~g} / \mathrm{L})$. Samples are put in water suspension during the analysis (Hydro 2000S module). Due to their compositional nature, a centred logratio (clr) transformation was applied to the data:

$$
x_{n}=\ln \frac{x_{i}}{G\left(x_{i}\right)}
$$

where, $x_{n}$ is the transformed data, $x_{i}$ is the original data, and $G$ the geometric mean of the $x_{i}$ variable. Data resulting from the clr transformation were used to build a cluster tree by performing hierarchical cluster analysis (CA). The groups were obtained using the Euclidian distance between samples and the Ward algorithm for clustering. To compare the dissolution silicate residue trapped in carbonate nodules with the embedding soil matrix, this specific fraction was taken as a group without going through clr and CA processing. Each cluster is represented by its median and standard error of its median ( $\sigma$ median):

$$
\sigma_{\text {median }}=1.253 \frac{\sigma}{\sqrt{n}}
$$

where, $\sigma$ is the standard deviation of samples composing a cluster and $\mathrm{n}$ the number of samples composing each cluster. For graphical reasons, the data are logarithmically transformed into phi $(\Phi)$ values using the expression proposed by Krumbein in 1934 (Blott and Pye, 2001):

$$
\phi=-\log _{2} d
$$


where, $d$ is the grain-size in millimetres. Clay percentage interpolation $(n=89)$ was performed using a cubic interpolation with Matlab (R2014a 8.3.0.532).

X-Ray Diffraction (XRD) analyses were performed with both $<2 \mu \mathrm{m}$ and 2-16 $\mu \mathrm{m}$ fractions. Carbonate was removed from dried $2 \mathrm{~mm}$-sieved soil samples with $10 \%$ $\mathrm{HCl}$ in an ultra-sonic bath for 3 minutes. The residual fraction was washed in order to remove the excess $\mathrm{HCl}$. Separation of the $<2 \mu \mathrm{m}$ and 2-16 $\mu \mathrm{m}$ fractions was performed by centrifugation and deposited on separate glass plates. Five samples per cluster resulting from the CA analysis were selected and prepared for XRD analyses, which were performed using an ARL Xtra diffractometer (Thermo). Clay minerals were identified according to their diffraction properties, i.e. the spacing ( $d$ ) between rows of atoms and the angle of incidence $(\theta)$, defined by Bragg's law:

$$
2 d \sin \theta=n \lambda
$$

where, $n \lambda$ is the number of wavelengths (Moore and Reynolds, 1997). The software PeakFit $^{\mathrm{TM}}$ (Systat Software Inc.) was used to deconvolve two parts of the diffractograms in order to discriminate between the different components combined in the signal (Velde and Meunier, 2008). The first part ranges from $4^{\circ} 2 \theta$ to $11^{\circ} 2 \theta$ and refers to smectite, illite and interlayered illite-smectite. The second part ranges from $23^{\circ} 2 \theta$ to $26^{\circ} 2 \theta$ and refers to the second peak of kaolinite and the fourth peak of the chlorite, which are overlapping. Kaolinite and chlorite were calculated as follows:

$$
\begin{aligned}
& \text { Kaolinite }(c p s)=C K 001 *\left(\frac{K 002}{K 002+C 004}\right) \\
& \text { Chlorite }(c p s)=C K 001 *\left(\frac{C 004}{K 002+C 004}\right)
\end{aligned}
$$

where, CK001 is the first peak of the kaolinite overlapping the second peak of chlorite occurring at about $12.5^{\circ} 2 \theta, \mathrm{KOO} 2$ is the second peak of the kaolinite occurring at about $24.2^{\circ} 2 \theta$, and $\mathrm{C} 004$ is the fourth peak of chlorite occurring at about $25.1^{\circ} 2 \theta$ (Moore and Reynolds, 1997).

The signals were first smoothed and deconvolved with the residue method using the Pearson VII operator. Relative percentages were calculated for smectite, illite, chlorite and kaolinite. However, only the results for smectite and kaolinite clay minerals are presented in this study.

\subsection{Thin section descriptions}


Thin section observations are used to identify pedogenic processes involved in the mima-like mound formation and to highlight the differences between sediments observed in the landscape. Thin section descriptions are performed according to the guidelines given in Stoops (2003). Particular attention is paid to the groundmass and the identification of pedofeatures, as they indicate lithology and weathering processes, as well as past and present pedogenic processes, respectively (Stoops, 2003). The characterization of the b-fabric, which is based on the patterns of orientation and distribution of interference colours in the soil micro-mass, is the main descriptor of groundmass, whereas, coatings, infillings, and nodules are mainly considered as pedofeatures (Stoops, 2003). Descriptors such as size, abundance, boundary, sorting, shape, sphericity, roughness, roundness, orientation, mineralogy, and colour, are used to differentiate the fabric units and patterns. The $\mathrm{c} / \mathrm{f}$ related distribution, which is the ratio between individual fabric units, small fabric units, and associated pores (Stoops and Jongerius, 1975), is used to describe the relationships between coarse and fine elements of the fabric.

\section{Results}

\subsection{Field and soil descriptions}

The studied mima-like mounds are located in the Mayo Tsanaga granitic watershed (Fig. 1B). They are distributed within stream networks and are regularly spaced (Fig. 1C) with $R=1.72$ (see appendix, Fig. A.1) meaning over-dispersion (Clark and Evans, 1954). They are easily identified because of their sparse vegetation cover (Fig. 2A) and their darker colour (Fig. 3). The size of the mounds is up to $10 \mathrm{~m}$ in diameter and up to $1 \mathrm{~m}$ in height (Fig. 2B). Their nature can be referred to as the clay-rich pediment layer described by Sieffermann (1967) and Morin (2000), to which carbonate nodules are often associated (see section 2).

Field observations showed that mima-like mounds have various heights; some are flattened, whereas others have whaleback morphologies (Fig. 4A, 4B). A fine beige alluvium surrounds all the various types of mima-like mounds (Fig. 3, 4C). In less eroded and well-preserved areas, a red-brown fersiallitic pediment, described by Sieffermann (1967) and Morin (2000), overlies them (Fig. 3, 4A). Some flattened mima-like mounds are also partially buried by a coarse alluvium interfingering with the clay-rich sediment (Fig. 4B). The various observed morphologies are undoubtedly related to the intensity of erosion processes (Fig. 4). The peculiarity of mima-like 
mounds is that their surface is completely covered by carbonate nodules $(2 \mathrm{~cm}<$ diameter $<10 \mathrm{~cm}$ ) and Fe-Mn micro-nodules (Fig. 2B). These nodules can also be found in deeper horizons (Fig. 2C, Table 1).

In the studied areas, the thickness of the clay-rich sediment composing mima-like mounds is still unknown, as its base could not be reached. However, according to Morin (2000), it can be up to several meters (about $6 \mathrm{~m}$ ) in the northwestern area of Mora. Nevertheless, field observations suggest that this clay-rich sediment has no genetic relationship with the granitic bedrock. Morin (2000) reported the following sedimentary and lithological succession in the region, from top to bottom: (i) clays with sand lenses, corresponding to the sediment composing the mima-like mounds, on (ii) a ferruginous duricrust, overlaying (iii) a saprolite directly developed from the cratonic rocks. However, the clay-rich sediment seems genetically related neither to the ferruginous duricrust nor the granitic bedrock. A mima-like mound deposited directly with a sharp unconformity on granitic inselbergs emphasizes the lack of any kind of causal relationship (Fig. 4D). However, more arguments are needed to strengthen this assumption.

Twenty-seven soil profiles were described along the trenches and descriptions are given in Table 1. The soils contain a very small amount of organic matter (less than $1 \%$ ) and are essentially mineral (Fig. 5). The structure is single grain to angular blocky in the surficial horizons, becoming angular blocky to prismatic or massive with depth. Some vertical cracks are visible in mound M3 below $10 \mathrm{~cm}$ (Fig. 5A, 5B, arrows). Mound M1 shows some preferentially orientated cracks, such as in profile $D$ (Fig. 5C, top, arrows). However, the structure of M1 is angular blocky to massive in depth (Fig. 5C top, ped), and vertical cracks are locally visible but to a lesser extent compared to M3 (Fig. 5C, bottom, arrow). Carbonate nodules (Fig. 5, white squares) and Fe-Mn oxides compose the skeleton; soil colour is yellowish-grey and $\mathrm{pH}_{\mathrm{H}} \mathrm{O}$ is alkaline $\left(8<\mathrm{pH}_{2} \mathrm{O}<10\right)$. The fine earth reacts to $\mathrm{HCl}$ indicating the presence of diffuse carbonate (Table 1). However, the coarse alluvium interfingering the clay-rich sediment in mound M2 has a single grained structure with a skeleton composed of silicate minerals, mainly quartz and feldspars, and a dark yellowish brown soil colour. The fine earth does not, or only weakly, react to $\mathrm{HCl}$ and $\mathrm{pH}_{\mathrm{H} 2 \mathrm{O}}$ are $7<\mathrm{pH}_{\mathrm{H} 2 \mathrm{O}}<8$. The dark brown fersiallitic pediment has a sub-angular blocky structure with a skeleton composed of silicate minerals. The fine earth does not react to $\mathrm{HCl}$, and $\mathrm{pH}_{\mathrm{H} 2 \mathrm{O}}$ is around 7. However, the lower part of the fersiallitic pediment displays the 
same properties as the mima-like mound soils, with a massive structure, a yellowishgrey soil colour, a $\mathrm{pH}_{\mathrm{H} 2 \mathrm{O}}>8$ and a fine earth weakly reacting to $\mathrm{HCl}$.

\subsection{Grain-size distribution}

Cluster analysis of grain-size distributions of all sediment samples (Fig. 6) generates seven clusters (with a cophenetic correlation coefficient of 0.54, $n=207$ ). Each cluster is represented by its median (Fig. 6, black lines) and its associated standard error (Fig. 6, grey-shaded areas). The median and its error are plotted as an independent cluster ( $n=10$, no clr and no CA processing) for the silicate residue trapped within the carbonate nodules, for comparison with other sediments. Six main modal classes $\left(\mathrm{mc}_{\mathrm{i}}\right)$ have been recognized (Fig. 6): $\mathrm{mc}_{1}$ ) coarse-medium sands, $\mathrm{mc}_{2}$ ) medium-fine sands, $\mathrm{mc}_{3}$ ) very fine sands-coarse silts, corresponding to the desertic lœss window (Crouvi et al., 2010), mc4) fine silts, mc5) coarse clays, and, finally, mc6) fine clays. These modal classes display various relative amplitudes and are used to characterize each cluster type.

The samples belonging to mound $M 3$, especially those found on the lower edge of the mound, are in the first cluster $(n=18)$. Cluster 1 is characterized by five modal classes, listed from higher to lower amplitudes: $\mathrm{mc}_{5}>\mathrm{mc}_{3}>\mathrm{mc}_{1}>\mathrm{mc}_{4}>\mathrm{mc}_{6}$. The second cluster $(n=21)$ is fairly similar to cluster 1 , with the same five modal classes characterized by similar amplitudes, except $\mathrm{mc}_{1}$, which is shifted toward the coarse sands. It groups samples from the upper edge of mound M3 and from both convex sides of mound M1. Cluster $3(n=41)$ groups samples from the surface of mound M1 and five modal classes are identified: $\mathrm{mc}_{5} \approx \mathrm{mc}_{3}>\mathrm{mc}_{1}>\mathrm{mc}_{4}>\mathrm{mc}_{6}$. The alluvium deposited on the sides of mounds $\mathrm{M} 1, \mathrm{M} 2, \mathrm{M} 3$, and the transitional part between the fersiallitic pediment and the clay-rich sediment in $\mathrm{P}$, are represented by cluster 4 $(n=16)$. This cluster is characterized by four modal classes: $m_{c_{1}}>m_{3}>m_{5}>m_{4}$. Samples from the core of mounds M1, M2, and the deeper part of $P$ are grouped in cluster 5 ( $n=54)$. This cluster is characterized by five modal classes: $m_{3}>m_{5}>m_{4}$ $>m_{1}>$ mc6. Cluster $6(n=52)$ is fairly similar to cluster 5 , except that $m_{1}$ mode is shifted toward very coarse sand. Samples from the core of $M 3$ are found in this cluster. Finally, surficial horizons from the fersiallitic pediment $P$ are displayed in cluster $7(n=5)$, with the following mode amplitudes: $m_{3}>m_{2}>m_{4}>m_{5}$. The carbonate nodule residue group $(n=10)$ is characterized by the following 4 modes listed from higher to lower amplitudes: $\mathrm{mc}_{3}>\mathrm{mc}_{5}>\mathrm{mc}_{4}>\mathrm{mc}_{1}$. 
Table 2 summarizes the mean, the minimal and maximal values of the clay, silt and sand contents (\%) for each cluster and for the silicate residue trapped inside the nodules. The maximal clay proportions in the clay-rich sediment are $>30 \%$ and can reach $67 \%$ (e.g. in cluster 2). However, the clay content can also be fairly low, e.g. in clusters 3,5 , and 6 . In clusters 5 and 6 , mean values are close to $20 \%$. As expected, alluvium and fersiallitic pediment have high proportions of sand, i.e. $47.6 \pm 6 \%$ and $63.2 \pm 10.1 \%$ in average, respectively. The silt-fraction is high, between 30 and $55 \%$ in all the clusters. The silicate residue trapped inside the nodules has a high silt fraction content $(52.2 \pm 3.5 \%)$ and displays a maximal clay value of $39.2 \%$. The sand proportion is around $20 \%$.

At the mound scale, highest proportions in the clay fraction (50-70\%) are found in both convex sides and in the deepest layers of mound M1 (Fig. 7, mound M1 see Fig. 2B). The lowest values of clay content $(<20 \%)$ are concentrated in a belt located in the middle part of the mound and at both extremities.

\subsection{Clay mineralogy}

Smectite and kaolinite are the main clay minerals composing the clay-rich sediment, the alluvium, and the silicate residue trapped in the carbonate nodules, whereas kaolinite is clearly dominant in the fersiallitic pediment (represented by cluster 7; Table 2). Regarding the smectite/kaolinite ratio $(S / K)$ of samples belonging to each grain-size cluster and carbonate nodule residues (Table 2), their mean values are above 1 in clusters 1, 6 and for carbonate nodule residues. They range from 0.5 to 1 in clusters 2, 5, and 4, and are $<0.5$ in clusters 3 and 7 . In terms of absolute values, the lowest $\mathrm{S} / \mathrm{K}$ is about 0.04 in the fersiallitic pediment. High ratio values are $<1$ in clusters 3 and 7 , between 1 and 1.5 in clusters 2, 5, 6, and 4 , and finally $<2$ in cluster 1 and in carbonate nodule residues.

\subsection{Soil micromorphology}

Soil thin sections from mound M1 were sampled between $10-18 \mathrm{~cm}$ and $90-98 \mathrm{~cm}$, respectively (Fig. 8A, 8B). Thin sections were also made in coarse and fine alluvium sediments (Fig. 8C, 8D, respectively), and the fersiallitic pediment (Fig. 8E, 8F).

The aggregate microstructure of the soil composing the mima-like mound (Fig. $8 \mathrm{~A}$ ) is angular blocky, with long horizontal and vertical channel voids between aggregates. The groundmass is composed of a very fine and unrecognizable clay fraction, with a 
pale yellow and striated b-fabric (Fig. 8A, white arrows). The cross-striated nature of the b-fabric is better observed at higher magnification (Fig. 8B, white and grey arrows). The groundmass also includes a coarse silt fraction: the grains are essentially composed of quartz and sparse epidote, feldspar, and biotite. The grains display a weakly weathered pattern, with a high sphericity, smooth edges, but an angular roundness. The two major pedofeatures are Fe-Mn oxyhydroxide nodules and carbonate nodules. They both are disorthic nodules, enclosing skeleton grains of similar nature to their surrounding matrix, but with sharp boundaries.

The coarse alluvium partially burying the flattened mound M2 was sampled between 23 and $30 \mathrm{~cm}$ for thin sections (Fig. $8 \mathrm{C}$ ). Peds are subangular blocky. The groundmass is yellowish-brown, displayed as coatings around mineral grains but also as broken coatings floating between the grains (Fig. $8 \mathrm{Cll}$ ). The coarse material is sandy and composed of microcline, quartz, epidote, biotite, and feldspars. The only pedofeature is an anorthic Fe-Mn oxyhrydroxide nodule. Finally, the c/f related distribution is chitonic.

The structure of the fine-grained alluvium surrounding mound M1 $(2-10 \mathrm{~cm})$ is horizontal and laminated (Fig. 8D). The coarse fraction (mainly silt-sized) in the groundmass is well sorted and composed of quartz, feldspars, epidote, and biotite. There is no fine material in the groundmass, except that associated with some rare relic peds (yellowish-brown b-fabric). Anorthic Fe-Mn oxyhydroxide nodules and fibrous organic components are the only observed pedofeatures. Finally, the c/frelated distribution is coarse monic.

The structure of the peds in the fersiallitic pediment $(40-48 \mathrm{~cm})$ is angular blocky (Fig. $8 \mathrm{E})$. The colour of the groundmass varies from pale yellow to yellowish-red. It is granostriated and porostriated, and coatings are randomly orientated. Two classes of grain-sizes are observed, one in the fine silt fraction and another in the fine sand fraction. Grains are mainly quartz and feldspars (weakly weathered), with a smooth angular shape. Epidote and biotite are also present as accessory minerals.

The b-fabric of the groundmass in the fersiallitic pediment (between 14 and $20 \mathrm{~cm}$ ) is granostriated and its colour varies from yellow to red (Fig. 8F). There are two major grain-sizes, a fine silt and a fine sand fraction. In the silt fraction, angular quartz and feldspar grains are mainly smooth. The sand fraction displays the same mineralogy, with smooth- and subangular-shaped grains. Both fractions are weakly weathered. 


\section{Discussion}

The presence of mima-like mounds in eroded areas from the landscape supports that erosion processes are involved in their morphology. Field observations show that vegetation patterns do not have a role in mound formation (Fig. 2A, 3). The question of another biotic factor (termite activity?) may be involved is not totally ruled out, especially as the over-dispersion spacing of the mounds may support a biotic origin (Cramer and Midgley, 2015). Nevertheless, up until now, observations pointed to an abiotic origin for mima-like mounds from northern Cameroon. Interestingly, the clayand carbonate-rich sediment composing mima-like mounds has already been described. It was observed (i) at various depths in all the Diamare piedmont (i.e. in the Mora and Kaele plains), (ii) outcropping on the southern bank of the Mayo Tsanaga (Siefferman, 1967; Brabant and Gavaud, 1985; Morin, 2000), and (iii) was even observed farther away in the Chad Basin between the Logone and Chari rivers (Erhart, 1954; Pias, 1962; Bocquier, 1973). Consequently, these repeated occurrences have led this sediment to be interpreted as an extended layer, possibly associated to a specific regional deposition event (aeolian, palustrine?). But how can mound morphologies be explained? Another interesting point is that mima-like mounds systematically occur in areas described as hardés or degraded soil (Fig. 1B), questioning the role of pedogenesis in their formation.

\subsection{Mima-like mounds as Vertisol relics}

Vertisols are clay-rich soils with a content $\geq 30 \%$ in the $<2 \mu \mathrm{m}$ size fraction (Wilding, 2004; Southard et al., 2011; FAO, 2014). The smectitic group of swelling clays (e.g. montmorillonite) represents the main soil clay mineralogy. Consequently, soils swell and shrink when they undergo marked changes in their soil moisture content (Hubble, 1984, Dudal and Eswaran, 1988; Mermut et al., 1996; Southard et al., 2011). Swell-shrink processes induce important volume variations in the soil (Southard et al., 2011). They can shape the ground surface with an alternation of knolls and depressions, known as gilgai micro-relief (Prescott, 1931; Oakes and Throp, 1950; Hallsworth et al., 1955; Mermut et al., 1996). They also lead to characteristic macro-features in the solum, such as vertical cracks, slickensides (or grooved shear planes), and cyclic horizons, organised in micro-low, micro-high, and intermediate parts at all depths (Wilding and Tessier, 1988; Eswaran et al., 1988, Wilding et al., 1990). The presence of a vertic horizon characterized by these macro- 
features is needed to define a soil as a Vertisol (FAO, 2014). According to Wilding et al. (1990), micro-lows have deep A and Bss horizons, while micro-highs have a thin A horizon, without any Bss horizons. When present, a Bk horizon in the micro-highs is characterized by a higher content in hard secondary carbonate than in micro-lows. Today, climatic conditions in northern Cameroon (see section 2) are favourable for Vertisol genesis. In terms of their global distribution, about $60 \%$ are found in the Tropics (Wilding, 2004). Brabant and Gavaud (1985) described and mapped some Vertisols in the Diamare, but most of them are in the south bank of the Mayo Tsanaga, near Kaele, or downstream near the sand belt. In the studied sites where mima-like mounds are observed, Planosol, associated with Solonetz, is generally the soil type. However, independently of the nature of soil, the striking feature is that mima-like mounds are observed in degraded areas (hardés). Soil descriptions, grainsize distributions, clay mineralogy, and thin-section observations suggest that mimalike mounds can be interpreted as degraded Vertisols or Vertisol relics, which could possibly have evolved toward Planosol or Solonetz.

Soil observations demonstrate that cycling and vertical cracks are present in some parts of the mima-like mounds (Fig. 5). Vertical cracks are observable in the mound M3 (Fig. 5A, 5B). In soil profile D (M1), what can be interpreted as a Bss horizon seems to have been truncated (Fig. $5 \mathrm{C}$, top). Interestingly, the clay content in microlows can be slightly higher than in micro-highs (Yule and Ritchie, 1980; Mermut et al., 1996). The truncated Bss horizon is located on the perimeter of the mound M1, where the clay fraction reaches $67 \%$ (Profile D, Fig. 7). It may thus be interpreted as an ancient micro-low. Cracks are less visible in the profile $\mathrm{J}$ (Fig. 3C, down) compared to what is seen in M3. This could be due to the season in which the pictures were taken. In M3, they were taken during the dry season of July 2012 and in mound M1 in September 2013, during the wet season. The cracks generally occur during the dry season; it is likely that they were less visible in September. Nevertheless, the soil structure observed in mima-like mounds is typical of swellshrink processes. Fe-Mn oxides and carbonate nodules are significant components of mima-like mounds (Fig. 2B, 2C) and they are known to be common features in Vertisols (Wieder and Yaalon, 1974; Ahmad, 1983). Regarding grain-size distributions and clay mineralogy of the soil residue trapped in carbonate nodules, it is similar to the surrounding soil (Fig. 6, Table 2). Consequently, these nodules are secondary pedogenic carbonate nodules precipitated inside the mima-like mound soil 
matrix. However, in Vertisols, secondary carbonate nodules are generally observed in the Bk horizon, which occur at about $20 \mathrm{~cm}$ deep in micro-highs, or about $100 \mathrm{~cm}$ deep in micro-lows (Wilding et al., 1990, Kovda et al., 2003, 2006). In mima-like mounds, even if some nodules are observed in deep horizons, they accumulate in large amounts at the surface, forming a cover (Fig. 2B, 2C). It is likely that the erosion of the surficial horizons, leaving only the Bk horizon at the surface, explains this surficial nodule accumulation.

Regarding the grain-size distributions and the clay mineralogy in mima-like mounds, they are similar to what is generally expected in Vertisols. The clay content in mimalike mounds is high, with an average proportion of $32 \%$ (standard error of the mean = $0.935, \mathrm{n}=186$ ) and with maximum values reaching $67 \%$ (Table 2). In addition, they contain a high proportion of smectite (Table 2), which is significantly higher than in the overlaying fersiallitic pediment (mean $S / K$ ratio $=0.2 \pm 0.1$ ). However, even if these components seem to be key features of the sediment forming mima-like mounds, they do not strictly correspond to Vertisol characteristics. First of all, in some cases, the clay content can be $<30 \%$ (Table 2). The grain-size distribution shows that coarse clays are more abundant that fine clays, which is generally the opposite in Vertisols well-structured (McGarry, 1996). Moreover, kaolinite can be the main clay mineral composing the clay-size fractions, which is often the case at the mound surface (cluster 3, Table 2). But a potential and progressive denaturation of smectite or an exogenic and aeolian contribution can explain this. Regardless of the reasons why kaolinite is dominant, these observations show that smectite is not always the main clay mineral in the clay-rich sediment, whereas it should be in Vertisol (Coulombe et al., 1996a). At the microscale, the b-fabric is striated to cross-striated (Fig. 8A, 8B), which is common in clay-rich soils subject to shrink-swell processes (Dalrymple and Jim, 1984; Jim, 1990). These features are particularly observed in mima-like mounds and absent in the alluvium or the fersiallitic pediment. All these observations point to Vertisols, but not exclusively. Consequently, mima-like mounds from the Diamare piedmont are interpreted as "degraded Vertisols" or "Vertisol relics".

\subsection{From gilgai micro-relief to present-day mima-like mounds}

The mima-like mounds from the Diamare piedmont may thus be interpreted as Vertisol relics. Vertisol degradation implies that there was a phase during which the 
Vertisols developed and another phase when they were degraded and eroded. The Bio-Rhexistasy theory, proposed by Erhart (1967), illustrates this conjecture. He described two major environmental phases: (i) Biostasy phases are stable periods characterized by dense vegetation cover, high soil development and biogeochemical weathering, during which leaching processes, and biogeochemical deposits prevail. In contrast, (ii) Rhexistasy phases are characterized by instable periods due to drastic changes in ecosystems. The decrease of vegetation cover and the destabilization of soils due to hydric changes favour erosion and detrital sedimentary deposits. It is demonstrated that there is a critical threshold of $55 \%$ vegetation cover, below which erosion rates increase rapidly (Snelder and Bryan, 1995, in Goudie, 2013). At the regional scale, Vertisols are perfectly adapted to present-day climatic conditions and can easily develop in the Diamare piedmont because of the presence of clay-rich sediment. However, Vertisols are located at lower altitudes compared to mima-like mounds (Martin, 1961; Siefferman, 1967; Bocquier, 1973; Brabant and Gavaud, 1985). It can be hypothesized that the topography plays an important role for Vertisol genesis in this region. This is explained by their chemical properties. Vertisols must have a high content of clay with high surface area and usually be highly alkaline (Coulombe et al., 1996a). The cation exchange capacity in Vertisols is typically high, saturated with $\mathrm{Ca}^{2+}, \mathrm{Mg}^{2+}$, and $\mathrm{Na}^{+}$, depending on the clay mineralogy and the parent material. Moreover, the $\mathrm{pH}$ is often neutral to alkaline. These conditions, and a high silica activity, favour the stability and the formation of smectite (Eswaran and Wong, 1978). On the contrary, leaching processes and acidic conditions induce the denaturation of smectite and the formation of kaolinite, leading to the development of other types of soils (Eswaran et al., 1988). The mima-like mounds are presently located in eroded and degraded areas (hardés), but it is possible that these areas were not always degraded. Consequently, it is proposed that the extent of the area favourable to Vertisol genesis varied through time and reached mima-like mound locations under different climatic conditions.

To explain the link between Vertisol genesis and mound formation, it is interesting to note that the diameter of mima-like mounds, which can reach up to $10 \mathrm{~m}$, is consistent with what is commonly observed in a gilgai landscape. The common distance from the micro-high to the micro-low, or the radius, ranges from 2 to $5 \mathrm{~m}$ (Miller and Bragg, 2007). Consequently, Vertisol genesis could have been associated with a gilgai micro-relief, during a period when Vertisol areas were extensive. This 
period of widespread occurrence can be defined as a Biostasy phase (Fig. 9). Precipitation of secondary pedogenic carbonate nodules and Fe-Mn micro-nodules are linked to Vertisol genesis, and thus, to this phase as well. Then, a Rhexistasy phase occurred as a response to climatic changes, inducing a decrease in favourable areas for Vertisol genesis, and an increase in erosion processes (Fig. 9). The gilgai micro-relief might have favoured preferential runoff in micro-lows rather than in microhighs, inducing pejoration of landscape irregularities. Consequently, mima-like mounds observed in the present-day landscape are interpreted as residual microhighs and micro-lows inherited from the gilgai micro-relief and resulting from differential erosion (Fig. 9). Furthermore, the wind has probably played a determinant role as an erosion agent. The Sahel of West Africa is a place for high-velocity winds produced by intense baroclinal gradients. In these sub-humid to arid areas, wind erosion is important and creates a large panel of morphologies such as inverted relief or yardangs, for example, which are the result of wind deflation erosion (Goudie, 2013). The mima-like mounds might be the result of contemporary interactions of both aeolian and fluvial erosion systems. This erosion association is highly discussed (Goudie, 2013) but seems to be effective particularly under short-term climate changes (Bullard and Livingstone, 2002). Independently of the type of erosion agent, erosion of fine fractions from surficial horizons can explain the relative accumulation, or pavement, of secondary carbonate nodules and Fe-Mn micro-nodules, normally found in a deeper Bk horizon, as a layer at the mima-like mound surface (Fig. 2B). It also explains the high clay content in both sides of the mounds (Fig. 7), which are the remaining parts of ancient micro-lows (Fig. 9).

\subsection{Sediments adjacent to mima-like mounds and landscape changes}

Analyses of sediments adjacent to mima-like mounds provide evidence of landscape geomorphogenesis. The grain-size distributions in the alluvium (both fine and coarse) and in the fersiallitic pediment are represented in clusters 4 and 7, respectively (Fig. 6). These two clusters lack a clay fraction (Fig. 6, mc6). They are also different from each other with the presence of $\mathrm{mc}_{2}$ in cluster 7 and a significant higher amplitude of mc5 in cluster 4 . These variations can be explained by different sources of sediments and/or transportation parameters (Vandenberghe, 2013). From their mineralogy observed in thin sections (Fig. 8), they definitely differ in terms of transportation parameters rather than sources of sediment. 
Coarse alluvium includes some broken clay coatings and a fine yellow birefringence rim surrounds all mineral grains (Fig. $8 \mathrm{C}$ ). This type of chitonic c/f related distribution corresponds to periods of high energy (coarse fraction) followed by slow water flow, which resulted in impregnations by fine material (Mücher et al., 2010). Field observations showed that the coarse alluvium was interfingering the clay-rich sediment of mound M2 (Fig. 4B), suggesting contemporaneous deposition. In the fine alluvium (Fig. 8D), the fine fraction is only present as relic peds, demonstrating the contribution of some reworked soils. Moreover, the $\mathrm{S} / \mathrm{K}$ ratio in the alluvium varies between 0.45 and 1.23 , which is close to the values observed in the clay-rich sediment, emphasizing the reworking of this proximal sediment. The fersiallitic pediment shows a complete disorganization of the clay-Fe coatings in the deepest horizon (Fig. 8E), while they are poorly marked in the surficial horizon (Fig. 8F). This disorganization indicates that fersiallitic pedofeatures are probably inherited and the soil material reworked. Therefore, the fersiallitic pediment may instead be a fersiallitic pedolith (Retallack, 2001). In the landscape, this pedolith is always found above the clay- and carbonate-rich sediment (Fig. 3, 4). This suggests they were reworked at the same time as the Vertisol surficial horizons, during gilgai micro-relief erosion. This means that the fersiallitic soil developed during the same period as Vertisols, but upstream. These interpretations strengthen hypotheses of high erosion events (Rhexistasy phase) occurring in northern Cameroon after a phase favourable for soil development (Biostasy phase). Moreover, they emphasize the complexity of erosiondeposition processes in such terrestrial environments.

Finally, grain-size distributions (Fig. 6) for all the sediments, including the clay-rich sediment, show a common modal class belonging to the desertic lœss window (20$80 \mu \mathrm{m})$ defined by Crouvi et al. (2010). At the micro-scale, well-sorted, smooth, and angular quartz, feldspars, and a few epidote grains characterize this fraction (Fig. 8). These observations raise questions about a possible aeolian contribution to the sediments. Maley (1981) already proposed an allochtonous contribution of sediments to explain the wide extent of the clay-rich sediment layer in the Far North region of Cameroon. Later, Mpeck (1994) studied the formation of Doyang, located in the south bank of the Mayo Tsanaga, between Maroua and Kaele, a formation already studied by Sieffermann in 1967. Mpeck (1994) proved the aeolian origin for this silty clay-rich deposit and emphasized its probable reworking after deposition. As previously demonstrated, field observations suggest the absence of a genetic 
relationship between the granite bedrock and the clay-rich sediment (Fig. 4D), making its origin as a simple result of granite bedrock weathering unlikely. Nevertheless, more investigations are needed to strengthen the hypothesis of an aeolian contribution to the mima-like mound area.

\subsection{Are mima-like mounds inherited from Late Pleistocene-Holocene climatic changes?}

Two main phases can thus explain mima-like mounds (Fig. 9); (i) during Biostasy, the Vertisol area was extended, and (ii) during Rhexistasy erosion increased, leading to Vertisol degradation in areas corresponding to the present-day mima-like mound locations. The shift from one phase to another probably results from regional climatic forcing. It is proposed that the extent of Vertisol areas were related to wetter conditions than nowadays. An increase in erosion, and thus the formation of mimalike mounds, can result from a serious decrease in the vegetation cover induced by climate change from wetter toward drier conditions. With these two environmental constraints, it is possible to discuss the potential role of Quaternary climatic changes in the Chad Basin area.

During the Quaternary (Fig. 10), the main climatic changes in the African tropics are related to the intensity and the latitudinal position of the monsoon front (or ITCZ Inter-Tropical Convergence Zone), which is a thermodynamic heat response to orbital forcing (deMenocal et al., 2000; Mayewski et al., 2004; Wanner et al., 2008; Lézine et al., 2011; Shanahan et al., 2015). From ca. 14.8 to 5.5 ka BP, a strengthening and a northward expansion of the African monsoon system, due to a gradual increase of the Northern Hemisphere summer insolation, led to a climatic optimum, known as the African Humid Period (AHP; deMenocal et al., 2000; deMenocal and Tierney, 2012; Shanahan et al., 2015). This period is characterized by a higher rainfall rate and a general northward displacement of the vegetation zonation by $400-500 \mathrm{~km}$, in conjunction with the monsoon system shift (Lézine, 1989; Hély et al., 2009). However, the climatic conditions during Holocene were unstable and marked by hydrological variations (Mayewski et al., 2004). Several studies showed differences between Early Holocene (9.5-8 ka BP) and mid-Holocene (6.5-5 ka BP; Maley, 1983, 2010; Gasse, 2000; Lézine et al., 2011). Lézine et al. (2011) examined more than 1500 palaeohydrological records collected between 10 and $28^{\circ} \mathrm{N}$ in the Sahara and the Sahel in Africa and demonstrated that a reduced and 
fragmented geographical extent of lakes and wetlands occurred during the Early Holocene (9.5-8 ka BP) compared to mid-Holocene (6.5-5 ka BP). The widespread extent of humid sectors in the mid-Holocene can be attributed to high groundwater levels, which might have been filled during Early Holocene, when maximum rainfall was recorded. In these conditions, the humid areas might have been widespread during the mid-Holocene, even if rainfall decreased (Lézine et al. 2011). Therefore, it is likely that the extent of Vertisol areas associated with a gilgai micro-relief has varied in the Diamare piedmont during the AHP. These variations may be concomitant with humid sector variations. Vertisol genesis in the Diamare piedmont might therefore be related to palustrine areas.

The contemporaneous deposition of the coarse alluvium and the clay-rich sediment implies changes in transportation energy. As demonstrated above, climate was not stable during the AHP. Servant (1983) already identified rainfall changes around $7 \mathrm{ka}$ $\mathrm{BP}$, due to the slight migration of the monsoon front position towards the south (Fig. 10). The rainfall regime is directly associated with this front. Dhonneur (1974) demonstrated that cumulonimbus clouds are dominant preceding the monsoon front and associated with big raindrops $(>2 \mathrm{~mm}$ ); on the other hand, stratus clouds are dominant behind the front, and their associated raindrops are smaller $(<2 \mathrm{~mm})$. Consequently, before $7 \mathrm{ka} \mathrm{BP}$, fine sedimentary deposits are favoured, whereas after 7 ka BP, coarse-grained sediments are dominant (Maley, 1983; Servant, 1983). Another process can be related to variations in the Lake Chad water level, which is the base level of rivers draining into the Chad Basin, such as the Mayo Tsanaga (Fig. 1B). Leopold and Bull (1978) defined the base level of a river as the elevation below which a stream cannot flow. The base level changes would have caused disequilibrium in river profiles: if it rises, the whole profile will tend to be raised by increasing accommodation space and then favouring deposition processes and fine material production; if it lowers, the profile will tend to be lowered by increasing erosion and coarse material production (Davis, 1902). Several studies showed that the lake level would have varied several times during the Holocene (Durand, 1982, 1995; Ghienne et al. 2002; Maley, 2004; Bouchette et al., 2010). Both runoff change processes due to rainfall and/or base level changes might have induced transportation energy changes able to explain the coarse alluvium/clay-rich sediment interfingering. 
The AHP ended around 5.5 ka BP (Fig.10), mainly because of the weakening and the southward migration of the monsoon front (Kröpelin et al., 2008; deMenocal and Tierney, 2012; Shanahan et al., 2015). Even if it is known that another humid phase occurred between 3.5-2.5 ka BP (Lézine, et al., 2011), it never reached the same maximum of rainfall. Nevertheless, efficient Vertisol genesis cannot be excluded during this period as well, and another erosion period might have been initiated again at the end of this second wet phase. However, it is likely that erosion might have increased with drier conditions and a decrease in vegetation cover. Consequently, it is probable that the Rhexistasy phase might be related to the end of the AHP.

Finally, the question remains of the potential aeolian origin of the material composing all the sediments. It was demonstrated that aeolian sediments are generally mobilized under dry conditions and stabilized during wet conditions, due to the increase of vegetation cover and soil moisture (Kocurek, 1998; Swezey, 2001; Vandenberghe, 2013). McTainsh (1984) showed that the isohyet of $400 \mathrm{~mm} / \mathrm{yr}$ is the minimum for dust stabilization. It is recognized that during the climato-sedimentary event, known as the Bossoumian II (from 15 ka to 13 ka BP; Hervieu, 1969, 1970; Maley, 1981; Brabant and Gavaud, 1985; Morin, 2000), fine aeolian deposits were favoured (Fig. 10). However, Durand (1995) showed that aeolian stabilization might have already been possible since $20 \mathrm{ka} \mathrm{BP}$ (Kanemian climato-sedimentary event). $\mathrm{He}$ demonstrated that the ergs observed in northern Cameroon and northeastern Nigeria, which represent the maximal extent of the Sahara, were probably formed before $28 \mathrm{ka} \mathrm{BP}$ and thus much older than the Kanemian. Consequently, the Kanemian was not as dry as was previously thought, and it is not excluded that the $400 \mathrm{~mm} / \mathrm{y}$ isohyet might have been effective since $20 \mathrm{ka} \mathrm{BP}$, leading to the possible stabilization of aeolian material.

In summary, the following chronological succession is proposed: (i) a pre-AHP period, during which aeolian material is deposited and probably reworked and mixed with the local material along the slopes, (ii) an AHP period, during which Vertisol developed, associated to gilgai micro-relief and secondary mineral precipitation; the extent of Vertisol was larger than nowadays, and during this period, fersiallitic soils were developing upstream Vertisols; and finally, (iii) a post-AHP period, during which erosion increased, forming the present-day mima-like mounds and reworking the fersiallitic soil above the clay-rich sediment. However, dating constraints are needed to support and improve the proposed chronology. Nevertheless, mima-like mounds 
and their adjacent sediments offer a great potential for the sedimentary record of the Chad Basin.

\section{Conclusions}

Investigations on newly observed earth mounds in the Chad Basin led to an original interpretation of their formation. According to their size and spatial distribution, they can be defined as mima-like mounds (Cramer and Barger, 2014). Recently it was postulated that mima-like mound shapes result from the combination of erosion and/or aeolian and vegetation patterns. Mima-like mounds observed in northern Cameroon are strongly linked to erosion, and there is no evidence that vegetation patterns play or played any particular role. Field observations and analytical results, such as grain-size distribution, clay mineralogy, and thin section observations show mima-like mounds to be degraded Vertisols or Vertisol relics developed in a former gilgai micro-relief. Erosional processes induced the stripping of surficial horizons of Vertisols and the accentuation of the gilgai micro-relief. They also induced the formation of a large accumulation of pedogenic nodules at the mound surface, remains of a former Bk horizon. In addition, a fersiallitic pedolith (e.g. reworked soil) buries them at some places in the landscape and this highly supports the occurrence of erosion events at some points. Present-day climatic conditions in the region of northern Cameroon are favourable to Vertisol genesis. But locally, climatic changes in the region during the Quaternary may have modified the extent of the Vertisol area. Larger areas of Vertisol can be related to widespread humid fields during the second part of the AHP during the Mid-Holocene (Biostasy phase). At the end of the AHP, climatic conditions became drier, inducing a decrease in vegetation cover and an increase in erosional processes (Rhexistasy phase). Moreover, water level fluctuations of Lake Chad and/or changes in the rainfall regime also occurred during the AHP, which might have influenced transportation-deposition processes in the Diamare piedmont. These changes would explain the occurrence of coarse alluvium interfingering the clay-rich sediment in a mima-like mound, which indicates a concomitant formation. Some questions are still pending regarding the origin of some fractions in the sediments from this landscape: all of them include a modal class corresponding to an aeolian component. Therefore, the possibility of a substantial aeolian contribution occurring before the AHP is proposed but this hypothesis 
remains open. Finally, the mima-like mounds from the Chad Basin have a significant potential as a regional sedimentary record.

\section{Acknowledgements}

The authors want to thank Dr. Jean-Louis Rajot and the other members of the Hydraride program (2011), who drew our attention to the mounds of the SudanoSahelian belt and collected the first samples from Niger and Burkina Faso. They also made the first observations in Northern Cameroon. The PEERS MORDRED insured the logistical aspects during the initial fieldwork in 2012. The LMI PICASS'EAU from the IRD and the members of Water and Environmental Sciences lab from the University of Ngaoundéré brought their help for logistic and technical support for fieldwork in 2013. Dr. Thierry Adatte (ISTE, University of Lausanne) performed XRD analyses. Authors also want to thank Aurélie Rubin and Yohan Ancey for $\mathrm{pH}$ measurements and sample preparation for clay mineralogy analyses. Authors appreciated substantial improving remarks given by Prof. Dr. Alain Durand and Karin Verrecchia on a first version of the manuscript. The authors would like to thank the two anonymous reviewers who provide extremely useful comments. The Swiss National Science Foundation supported this work (grant no 200021-147038).

\section{References}

Ahmad, N., 1983. Vertisols. In: L. P. Wilding et al. (Editors), Pedogenesis and Soil Taxonomy. Vol. II, The Soil Orders. Elsevier Science, New York, USA, 91-123.

Blott, S.J., Pye, K., 2001. GRADISTAT: A Grain-size distribution and Statistics Package for the Analysis of Unconsolidated Sediments. Earth Surface Processes and Landforms 26, 1237-1248.

Bocquier, G., 1973. Genèse et Evolution de Deux Toposéquences de Sols Tropicaux du Tchad. Interprétation Biogéodynamique. Mémoires de l'ORSTOM, Paris, France, p. 327.

Bouchette, F., Schuster, M., Ghienne, J.-F., Denamiel, C., Roquin, C., Moussa, A., Marsaleix, P., Duringer, P., 2010. Hydrodynamics in Holocene Lake Mega-Chad. Quaternary Research 73 (2), 226-236, doi:10.1016/j.yqres.2009.10.010. 
Brabant, P. and, M. Gavaud, 1985. Les Sols et les Ressources en Terres du NordCameroun. ORSTOM, Paris, France, 369 pp.

Bullard, J., Livingstone, I., 2002. Interactions between Aeolian and Fluvial Systems in Dryland Environments. Area 34, 8-16.

Butler, D.R., (1995). Zoogeomorphology: Animals as Geomorphic Agents. Cambridge University Press, Cambridge, UK.

Clark, P. J. and Evans, F. C., 1954. Distance to Nearest Neighbor as a Measure of Spatial Relationships in Populations. Ecology, 35(4), 445-453.

Coulombe, C.E., Dixon, J.B., Wilding, L.P., 1996a. Mineralogy and chemistry of Vertisols, in: Ahmad, N., Mermut, A.R. (Eds.), Vertisols and Technologies for their Management. Elservier Science, Amsterdam, The Netherlands, pp. 115-188.

Coulombe, C. E., Wilding, L. P., Dixon, J. B., 1996b. Overview of Vertisols : Characteristics and Impacts on Society. Adv. Agron., 57, 289-357.

Cramer, M.D., Barger, N.N., 2014. Are mima-like mounds the consequence of longterm stability of vegetation spatial patterning? Palaeogeography, Palaeoclimatology, Palaeoecology 409, 72-83, http://dx.doi.org/10.1016/j.palaeo.2014.04.026.

Cramer, M.D., Midgley, J.J., 2015. The distribution and spatial patterning of mimalike mounds in South Africa suggests genesis through vegetation induced aeolian sediment deposition. J. Arid Env. 119, 16-26.

Cramer, M.D., Innes, S.N., Midgley, J.J., 2012. Hard Evidence that Heuweltjie Earth Mounds are Relictual Features Produced by Differential Erosion. Palaeogeography, Palaeoclimatology, Palaeoecology 350-352, 189-197. 
Crouvi, O., Amit, R., Enzel, Y., Gillespie, A.R., 2010. Active sand seas and the formation of desert lœss. Quaternary Science Reviews 29 (17-18), 2087-2098, doi:10.1016/j.quascirev.2010.04.026.

Dalrymple, J. B. and Jim, C. Y., 1984. Experimental Study of Soil Microfabrics Induced by Isotropic Stresses of Wetting and Drying. Geoderma 34, 43-68.

Davis, W. M., 1902. Basel-level, Grade and Peneplain. Journal of Geology 10, 77111.

DeMenocal, P.B. and Tierney, E.J., 2012. Green Sahara: African Humid Periods Paced by Earth's Orbital Changes. Nature Education 3 (10), 12 pp.

DeMenocal, P.B., Ortiz, J., Guilderson, T., Adkins, J., Sarnthein, M., Baker, L., Yarusinsky, M., 2000. Abrupt Onset and Termination of the African Humid Period: Rapid Climate Responses to Gradual Insolation Forcing. Quaternary Science Reviews 19, 347-361.

Dhonneur, G., 1974. Nouvelle Approche des Réalités Météorologiques de l'Afrique Occidentale et Centrale. Thèse Doctorale Ing., Université de Dakar, ASECNA, Dakar.

Dudal, R. and Eswaran, H., 1988. Distribution, Properties and Classification of Vertisols. In : L. P. Wilding and R. Puentes (Editors), Vertisols: Their Distribution, Properties, Classification and Management. SMSS-Texas AandM University, 1-22.

Durand, A., 1995. Quaternary Sediments and Climates in the Central Sahel. Africa Geoscience Review 2 (3-4), 323-614.

Durand, A., 1982. Oscillations of Lake Chad over the Past 50,000 years: New Data and New Hypothesis. Palaeogeography, Palaeoclimatology, Palaeoecology 39, 37 53. 
Erhart, M. H., 1954. Bassin du Moyen Logone. In: Commission Scientifique du Logone et du Tchad, Etude Pédologique du Bassin Alluvionnaire du Logone-Chari. ORSTOM, Paris, France, 17-107.

Erhart, M. H., 1967. La Genèse des Sols en Tant que Phénomène Géologique. Esquisse d'une Théorie Géologique et Géochimique. Biostasie et Rhexistasie. Masson et Cie, Second Edition, Paris Vie, France.

Eswaran, H., and Wong, C. B., 1978. A Study of a Deep Weathering Profile on Granite in Peninsular Malaysia: I. Physico-Chemical and Micromorphological Properties. Soil Science Society of America Journal 42, 144-148.

Eswaran, H., Kimble J., and Cook, T., 1988. Properties, Genesis and Classification of Vertisols. Workshop Swell-shrink soils, October 24-28, National Bureau of Soil Survey and Land Use Plannign, Nagpur India, Oxford and IBH Publ. Co, New Delhi, India.

FAO, (2014). World Reference Base for Soil Resources 2014. International Soil Classification System for naming Soils and creating Legends for soil maps. World soil resources reports 106, Rome, Italy.

FAO, (2006). Guidelines for Soil Description. Food and Agriculture Organization of the United Nations (FAO), Rome, Italy.

FAO/GIEWS, (2004). Sahel weather and crop situation report. The rainy season has started against a backdrop of worrying desert locust situation. Sahel Report, 1, http://www.fao.org/docrep/006/J2517e/J2517e00.htm\#carte.

Francis, M.L., Ellis, F., Lambrechts, J.J.N., Poch, R.M., 2013. A Micromorphological View through a Namaqualand Termitaria (Heuweltjie, a Mima-like mound). Catena 100, 57-73.

Funch, R.R., 2015. Termite mounds as dominant land forms in semiarid northeastern Brazil. J. Arid Envi. 122, 27-29. 
Gasse, F., 2000. Hydrological Changes in the African Tropics Since the Last Glacial Maximum. Quaternary Science Reviews 19, 189-211.

Ghienne, J.-F., Schuster, M., Bernard, A., Duringer, P., Brunet, M., 2002. The Holocene Giant Lake Chad Revealed by Digital Elevation Models. Quaternary International 87, 81-85.

Goudie, A.S., 2013. Arid and semi-arid geomorphology. Cambridge University Press, New York, USA.

Hallsworth, E. G., Robertson, G. K., Gibbson, F. R., 1955. Studies in Pedogenesis in New South Wales. VII. The Gilgai Soils. Journal of Soil Science 6, 1-31.

Hély, C., Braconnot, P., Watrin, J., Zheng, W., 2009. Climate and Vegetation: Simulating the African Humid Period. Comptes Rendus Geoscience 341 (8-9), 671 688, doi:10.1016/j.crte.2009.07.002

Hervieu, J., 1970. Influence des Changements des Climats Quaternaires sur le Relief et les Sols du Nord-Cameroun. Bull. Ass. sénég. et Quatern. Ouest afr. 25, 97-105.

Hervieu, J., 1969. Le Quaternaire du Nord-Cameroun Schéma d'Evolution Géomorphologique et Relations avec la Pédogenèse. ORSTOM, Paris, France, 38 pp.

Hubble, G. D., 1984. The cracking clay soils : definition, distribution, nature, genesis and use. In: J. W. McGarity, E. H. Hoult and H. B. So (Editors), The properties and utilization of cracking clay soils, Review in Rural Science University of New England, Armidale, Australia, 5, 3-13.

Jim, C. Y. (1990). Stress, shear deformation and micromorphological clay orientation: A synthesis of various concepts. Catena 17, 431-447.

Kocurek, G., 1998. Aeolian System Response to External Forcing Factors. In: Alsharhan, A., Glennie, K., Whittle, G., Kendall, C. (Editors), Quaternary Deserts and 
Climatic Change. Balkema, Rotterdam, The Netherlands, pp. 327-337.

Kröpelin, S., Verschuren, D., Lézine, A.-M., Eggermont, H., Cocquiyt, C., Francus, P., Cazet, J.-P., Fagot, M., Rumes, B., Russell, J.M., Darius, F., Conley, D.J., Schuster, M., Von Suchodoletz, H., Engstrom, D.R., 2008. Climate-Driven Ecosystem Succession in the Sahara: The Past 6000 Years. Science 320, 765-768.

Kovda, I., Mora, C.I., Wilding, L.P., 2006. Stable Isotope Compositions of Pedogenic Carbonates and Soil Organic Matter in a Temperate Climate Vertisol with Gilgai, Southern Russia. Geoderma $136 \quad$ (1-2), 423-435, doi:10.1016/j.geoderma.2006.04.016

Kovda, I.V., Wilding, L.P., Drees, L.R., 2003. Micromorphology, Submicroscopy and Microprobe Study of Carbonate Pedofeatures in a Vertisol Gilgai Soil Complex, South Russia. Catena 54 (3), 457-476, doi:10.1016/S0341-8162(03)00121-8.

Leopold, L. B. and Bull, W. B., 1978. Base Level, Aggradation, and Grade. Proceedings of the American Philosophical Society 123 (3), 168-202.

Lézine, A.-M., Hély, C., Grenier, C., Braconnot, P., Krinner, G., 2011. Sahara and Sahel Vulnerability to Climate Changes, Lessons from Holocene Hydrological Data. Quaternary Science Reviews $30 \quad$ (21-22), 3001-3012, doi:10.1016/j.quascirev.2011.07.006

Lézine, A.-M., 1989. Late Quaternary Vegetation and Climate of the Sahel. Quaternary Research 32, 317-334.

L'Hôte, Y., 1998. Climatologie et Agroclimatologie de la Province Extrême-North (P. E. N.) du Cameroun. ORSTOM, Paris, France.

Mahop, F., Van Ranst, E., Boukar, S., 1995. Influence de l'aménagement des sols sur l'efficacité des pluies au Nord-Cameroun. Etude et Gestion des Sols 2 (2), 105117. 
Maley, J., 1981. Etudes Paylnologiques dans le Bassin du Tchad et Paléoclimatologie de l'Afrique Nord-Tropicale de 30000 ans à l'Epoque Actuelle. Palaeoecology of Africa 13, 45-52.

Maley, J., 1983. Histoire de la Végétation et du Climat de l'Afrique Nord-Tropicale au Quaternaire Récent. Bothalia 14 (3-4), 377-389.

Maley, J., 2004. Le Bassin du Tchad au Quaternaire Récent: Formations Sédimentaires, Paléoenvironnements et Préhistoire. La Question des Paléotchads. In: A.-M. Sémah and J. Renault-Miskovsky, Guide de la Préhistoire mondiale. Artcom' - Errance, Paris, France, 179-217.

Maley, J., 2010. Climate and Palaeoenvironment Evolution in North Tropical Africa from the End of the Tertiary to the Upper Quaternary. Palaeoecology of Africa 30, 227-278.

Martin, D., 1961. Carte Pédologique du Nord-Cameroun au 1/100.00e feuille de Mora. ORSTOM-IRCAM, Yaoundé, Cameroun.

Mayewski, P.A., Rohling, E.E., Curt Stager, J., Karlén, W., Maasch, K.A., David Meeker, L., Meyerson, E.A., Gasse, F., van Kreveld, S., Holmgren, K., Lee-Thorp, J., Rosqvist, G., Rack, F., Staubwasser, M., Schneider, R.R., Steig, E.J., 2004. Holocene climate variability. Quaternary Research 62 (3), 243-255, doi:10.1016/j.yqres.2004.07.001

McGarry, D., 1996. The Structure and Grain-size Distribution of Vertisols, in: Ahmad, N., Mermut, A.R. (Eds.), Vertisols and Technologies for their Management. Elservier Science, Amsterdam, The Netherlands, pp. 231-259.

McTainsh, G., 1984. The Nature and Origin of the Aeolian Mantles of Central Northern Nigeria. Geoderma 33, 13-37. 
Mermut, A. R., Padmanabham, E., Eswaran, H., Dasog, G. S., 1996. Pedogenesis. In: A. N. and A. R. Mermut, Vertisols and Technologies for Their Management. Elsevier Science B. V., Amsterdam, The Netherlands, 43-58.

Miller, W. L. and Bragg, A. L., 2007. Soil Characterization and Hydrological Monitoring Project, Brazoria County, Texas, Bottomland Hardwood Vertisols. The United States Department of Agriculture (USDA), Washington, D. C., USA, pp 333.

Moore D. M. and Reynolds, R.C., 1997. X-Ray Diffraction and the Identification and Analysis of Clay Minerals. Oxford University Press, New York, USA.

Moore, J.M., Picker, M.D., 1991. Heuweltjies (Earth Mounds) in the Clanwilliam District, Cape Province, South Africa: 4000-Year-Old Termite Nests. Oecologia 86, 424-432.

Morin, S. (2000). Géomorphologie. In: C. Seignobos and O. lyébi-Mandjek, Atlas de la Province Extrême-Nord Cameroun. Ministère de la Recherche Scientifique et Technique Institut National de Cartographie, Institut de Recherche pour le Développement, Cameroun, Paris, France.

Mpeck, E., 1994. Contribution des Poussières Sahariennes à la Sédimentation du Pléistocène Supérieur au Nord Cameroun: La Formation de Doyang. Thèse de Doctorat, Terre, Océan et Espace, Université Paris 6, Paris, France, pp 303.

Mücher, H., Van Steijn, H., Kwaad, F., 2010. Colluvial and Mass Wasting Deposits. In: Stoops, G., Marcelino, V., Mees, F. (Editors), Interpretation of Micromorphological Features of Soils and Regoliths. Elsevier Science, Amsterdam, The Netherlands, 3748.

Oakes, H. and J. Thorp, 1950. Dark Clay Soils of Warm Regions of Variously Called Rendzina Black Cotton Soils, Regurs and Tirs. Soil Science Society of America, Proceedings 15, 347-354. 
Olivry, J.-C., Chouret, A., Vuillaume, G., Lemoalle, J., Bricquet, J.-P., 1996. Hydrologie du Lac Tchad. ORSTOM, Paris, France, 301 pp.

Peel, M.C., Finlayson, B.L., McMahon, T.A., 2007. Updated World Map of the Köppen-Geiger Climate Classification. Hygrology and Earth System Sciences 11, 1633-1644.

Pias, J. 1962. Les Sols du Moyen et Bas Logone, du Bas Chari, des Régions Riveraines du Lac Tchad et du Bahr El Ghazal. Mémoires ORSTOM, Paris, France, $434 \mathrm{pp}$.

Prescott, J. A., 1931. The soils of Australia in relation to climate. The Commonwealth Scientific and Industrial Research Organisation (CSIRO) Australia Bull., 52, 65-67.

Retallack, G.J., 2001. Soils of the Past. An Introduction to Paleopedology. Blackwell Science Ltd, Oxford, United Kingdom.

Servant, M., 1983. Séquences Continentales et Variations Climatiques: Evolution du Bassin du Tchad au Cenozoïque supérieur, Travaux et Documents de I'ORSTOM, Paris, France, pp. 1-567.

Shanahan, T.M., McKay, N.P., Hugen, K.A., Overpeck, J.T., Otto-Bliesner, B., Heil, C.W., King, J., Scholz, C.A., Peck, J., 2015. The Time-Transgressive Termination of the African Humid Period. Nature Geoscience 8, 140-144.

Sieffermann, G., 1963. Carte Pédologique du Nord-Cameroun au 1/100.000e, feuille de Kalfou. ORSTOM-IRCAM, Yaoundé, Cameroun.

Sieffermann, G., 1967. Variations Climatiques au Quaternaire dans le Sud-Ouest de la Cuvette Tchadienne, C. R. 92e Congr. Nat. Soc. Sav., Strasbourg, Colmar, France, pp. 485-494.

Silva, L.C.R., Vale, G.D., Haidar, R.F., da S. L. Sternberg, L., 2010. Deciphering Earth Mound Origins in Central Brazil. Plant and Soil 336, 3-14. 
Southard, R.J., Driese, S.G., Nordt, L.C., 2011. Vertisols. In : Handbook of Soil Sciences Properties and Processes. P. M. Huang, Y. Li and M. E. Sumner. USA, CRC Press Taylor and Francis Group, 33-82.

Stoops, G., 2003. Guidelines for Analysis and Description of Soil and Regolith Thin Sections. Soil Science Society of America, Wisconsin, USA, 184 pp.

Stoops, G. and Jongerius, A., 1975. Proposal for a Micromorphological Classification of Soil Materials. I. A Classification of the Related Distribution of Coarse and Fine Particles. A reply. Geoderma 19, 247-249.

Swezey, C., 2001. Eolian Sediment Responses to Late Quaternary Climate Changes: Temporal and Spatial Patterns in the Sahara. Palaeogeography, Palaeoclimatology, Palaeoecology 167, 119-155.

Vandenberghe, J., 2013. Grain-size of Fine-Grained Windblown Sediment: A Powerful Proxy for Process Identification. Earth-Science Reviews 121, 18-30, http://dx.doi.org/10.1016/j.earscirev.2013.03.001.

Velde, B., Meunier, A., 2008. The Origin of Clay Minerals in Soils and Weathered Rocks. Springer, Berlin, Germany.

Wanner, H., Beer, J., Bütikofer, J., Crowley, T.J., Cubasch, U., Flückiger, J., Goosse, H., Grosjean, M., Joos, F., Kaplan, J.O., Küttel, M., Müller, S.A., Prentice, I.C., Solomina, O., Stocker, T.F., Tarasov, P., Wagner, M., Widmann, M., 2008. Mid- to Late Holocene Climate Change: an Overview. Quaternary Science Reviews 27 (1920), 1791-1828, doi:10.1016/j.quascirev.2008.06.013.

Wieder, M., Yaalon, D.H., 1974. Effect of Matric Composition on Carbonate Nodule Crystallisation. Geoderma 11, 95-121. 
Wilding, L. P. and Tessier, D., 1988. Genesis of Vertisols : Shrink-swell phenomena. In: L. P. Wilding and R. Puentes (Editors), Vertisols: Their distribution, properties, classification and management. SMSS-Texas AandM University, 55-82.

Wilding, L.P., Williams, D., Miller, W., Cook, T., Eswaran, H., 1990. Close Interval Spatial Variability of Vertisols : A Case Study in Texas. In: J. M. Kimble (Editor), Proc. Sixth Int. Soil Correlation Meeting (ISCOM). Characterization, Classification and Utilization of Cold Aridisols and Vertisols. USDA, Soil Conservation Service, National Soil Survey Center, Lincoln, USA, 232-247.

Wilding, L.P., 2004. Advancement in the Knowledge Base of Vertisols Genesis, Classification, Distribution and Management. Revista Cientifica Agropecuaria, 8(1), 45-54.

Yule, D. F. and Ritchie, J. T., 1980. Soil Shrinkage Relationships of Texas Vertisols, I : Small Cores. Soil Science Society of America Journal, 44, 1285-1291.

Figure and table captions

Figure 1: Location and settings of study sites. A) Location of observed sediments associated with carbonate nodules (circles) along the Sudano-Sahelian belt (MAP 900-500 mm/yr); mean annual precipitation ranges are given for the three climatic zones. The black rectangle refers to the location of the Far North region of Cameroon. B) Far North region of Cameroon map showing, from SW to NE, the Mandara Mountains, the Diamare piedmont, separated from the Yayres floodplain by a sand belt, and finally, Lake Chad. The stars represent the study sites. They are located in the Mayo Tsanaga watershed, which belongs to the Chad Basin (large dashed-line; Olivry et al., 1996). Circles indicate the location of the clay-rich sediment outcropping as mima-like mounds within stream networks (Google Earth observations, see Appendix Table A.1) and generally found in hardés areas or degraded soil areas reported by Brabant and Gavaud (1985). C) Example of a

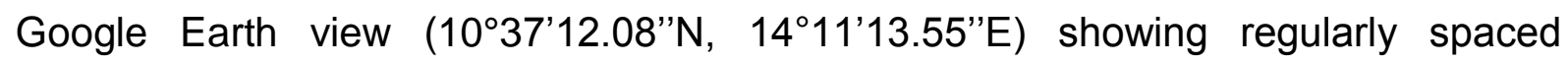
( $R=1.72$, over-dispersion, Clark and Evans, 1954, see appendix Fig. A.1) mima-like 
mounds outcropping in eroded areas between ephemeral streams. A beige alluvium surrounds them and less eroded areas display a reddish pediment interpreted as a fersiallitic pedolith (Relallack, 2001). Some granitic inselbergs outcrop as well.

Figure 2: A) Relationships between mima-like mounds and vegetation patterns. Generally, the clay-rich sediment is devoid of vegetation compared to surrounding sediments, and shows sharp limits (dashed line), which makes it easily recognizable in the landscape. B) Mima-like mound M1 located along the Mayo ${ }^{2}$ Tsanaga watershed (Fig. 1B, 2013 field observation) surrounded by a fine alluvium and covered by carbonate nodules and $\mathrm{Fe}-\mathrm{Mn}$ micro-nodules. C) Trench through the mima-like mound M1 composed by a yellowish-grey, clay-rich and massive soil matrix. A few carbonate nodules (black square) and Fe-Mn micro-nodules (black circle) are also observed in the soil skeleton ( $>2 \mathrm{~mm}$ ). Pictures taken in September 2013.

Figure 3: Mima-like mounds in the landscape. The clay-rich sediment outcrops as dark mima-like mounds at various stage in their development. Beige alluvium associated with ephemeral stream systems surround them. The fersiallitic pediment is always observed overlaying the clay-rich sediment.

Figure 4: Field relationships between clay-rich sediment morphologies and erosion intensity. The drawing represents a cross-section of the various sediments observed in the landscape and the relationships to each other. The pictures illustrate four different situations represented in the drawing (black rectangles). A) Detail of the fersiallitic pediment overlaying the clay-rich sediment (profile P). B) Example of a flattened mima-like mound (M2) in contact with a coarse alluvium interfingering the clay-rich sediment. C) Detail of the contact between the fine alluvium and the mimalike mound M1. D) Clear contact between a mima-like mound and the granitic bedrock. The thickness of the clay-rich sediment and its contact with a deep ferruginous duricrust described in the literature and/or the bedrock saprolite were not observed during the fieldwork. The clay-rich sediment outcrops as flattened mima-

\footnotetext{
${ }^{2}$ Term used to designate a stream in the Foulfoulde language. Nowadays, it is a local scientific term used as a synonym for ephemeral stream.
} 
like mounds, whaleback morphologies, or mima-like mounds depending on the intensity of erosion. A fersiallitic pediment buries mounds in less eroded parts of the landscape.

Figure 5: Soils observed in mima-like mounds. White squares highlight some carbonate nodules inside the soil profiles. A) Soil profile $Y$ in mima-like mound M3. The structure is angular blocky from surface to $10 \mathrm{~cm}$ deep and angular blocky to prismatic below $10 \mathrm{~cm}$ (dashed line limit). Below $10 \mathrm{~cm}$, slickensides are well developed and associated with vertical cracks (arrows). B) Soil profile W in mima-like M3. The structure is single-grained to angular blocky in the first $10 \mathrm{~cm}$ and angular blocky to prismatic below. Slickensides are also visible with vertical cracks (arrows). C) Top photo: soil profile D in mound M1. The structure is angular blocky in the first $30 \mathrm{~cm}$ and some preferentially oriented cracks are visible (arrows). The structure is massive below $30 \mathrm{~cm}$ and peds are blocky, although cracks are less visible. Bottom photo: soil profile $\mathrm{J}$ in mound $\mathrm{M} 1$. The structure is massive. Cracks, visible in the lower part of the profile, are not well developed (arrows). Pictures of mound M3 were taken in July 2012 and mound M1 in September 2013.

Figure 6: Grain-size distributions grouped in seven clusters represented by their median (black line) and its associated standard error (grey-shaded areas). The clusters were processed according to the Euclidian distance between the samples $(n=207)$ using the Ward agglomeration algorithm (with a cophenetic correlation coefficient of 0.54 ). Data were previously transformed using the centred log-ratio method. Six modal classes $\left(\mathrm{mc}_{\mathrm{i}}\right)$ are identified. Their respective presence and amplitudes are used to characterize each cluster. The dark rectangle around $4 \Phi$ represents the desertic lœss window $(20-80 \mu \mathrm{m})$ according to Crouvi et al. (2010). The cluster representing the silicate residue of carbonate nodules $(n=10)$ has not been included in the hierarchical clustering analysis in order to directly compare this particular group with other sediments from the landscape. In order to provide a maximum of information, the descriptive terminology used for sands and silts is adapted from the GRADISTAT program (Blott and Pye, 2001) and the one for the clays from the United States Department of Agriculture. Abbreviations: $v$ for very, $c$ for coarse, $m$ for medium and $f$ for fine. 
Figure 7: Distribution of the clay-size fraction (\%) in mima-like mound M1 according to a cubic interpolation $(n=89)$. Capital letters refer to profile names.

Figure 8: Illustrations of soil thin sections from the various sediments composing the landscape. The black arrow refers to the top. Following abbreviations are used: ox for Fe-Mn oxide nodule, nod for carbonate nodule, $f d$ for feldspar, $m c l$ for microcline, $q t z$ for quartz, ep for epidote, $b$ for biotite, $O M$ for organic matter and $\mathrm{Fe}$ - $\mathrm{Cl}$ for iron-clay coating. A) Mima-like mound (M1) between $10-18 \mathrm{~cm}$ : the groundmass is pale yellow and has a striated b-fabric, whose orientation is illustrated by the white arrows (crosspolarized light). B) Mima-like mound (M1) between $90-98 \mathrm{~cm}$ : the grey and white arrows show the cross-striated and striated orientation of the groundmass, respectively (cross-polarized light). The striated and cross-striated nature of the bfabric in the mima-like mounds ( $A$ and $B$ ) can be referred to as slickensides, which are typical features resulting from shrink-swell processes. C) Coarse alluvium interfingering the clay-rich sediment in M2 $(23-31 \mathrm{~cm})$ : a broken coating is shown in a white box (cross polarized light); the $\mathrm{c} / \mathrm{f}$ related distribution is chitonic with a fine yellow birefringence layer surrounding all minerals. D) Fine alluvium $(2-10 \mathrm{~cm})$ surrounding M1: several horizontal deposits are shown and highlighted by black dashed-lines; relict peds (shown by white arrows) show a c/f single-spaced porphyric, (plane-polarized light) and are found in a c/f coarse monic material. E) Fersiallitic pedolith between 40-48 cm (cross-polarized light): the groundmass varies from yellow to yellowish-red and coatings are randomly orientated. F) Fersiallitic pedolith between 14-21 cm (cross-polarized light): the groundmass is yellow to yellowish-red and displays a granostriated $b$-fabric.

Figure 9: Hypothetical erosion scenario leading to mima-like mound formation. Top: this figure is modified from Coulombe et al. (1996b) and shows Vertisol genesis associated with a gilgai micro-relief characterized by alternations of micro-highs and micro-lows. Secondary carbonate nodules form during Vertisol genesis in a Bk horizon, developing at $20 \mathrm{~cm}$ in micro-highs and at $100 \mathrm{~cm}$ in micro-lows. Bottom: mima-like mound, or residual gilgai micro-relief, after a phase of erosion and composed by relics of micro-lows and micro-highs (compare with Fig. 7). Vertisol genesis at mima-like mound locations may occur during a Biostasy phase, characterized by wetter conditions than in present-day; onset of erosion may 
correspond to a Rhexistasy phase, characterized by drastic changes in climatic conditions.

Figure 10: Summary of the main events that occurred in the Chad Basin during the Late Pleistocene-Holocene period and relationships with mima-like mound formation (ade Menocal et al., 2000; bHervieu, 1967, Brabant \& Gavaud, 1985; 'Hervieu1970, Maley, 1981, Maley, Morin, 2000, 2004; dLézine et al., 2011; 'Servant, 1983). Abbreviations: $L T$ for lacustrine transgression; Max for maximum. The African Humid Period lasted from 14.8 ka to $5.5 \mathrm{ka}$ BP; the extent of Vertisol areas in the Diamare piedmont is hypothesized to have varied during this period in concomitance with different climatic events (e.g. lake-level changes, extent of humid areas) and may have been larger than in the present-day. This period can be referred to as a Biostasy phase. A climate change, inducing an increase of erosional processes characterized the end of the AHP. Vertisol erosion in a gilgai micro-relief is likely at the origin of the present-day mima-like mound landscape. This period can be referred to as a Rhexistasy phase. The time limits of all these phases are uncertain and illustrated by dashed lines and arrows.

Table 1: Soil profile descriptions according to FAO (2006)'s descriptive codes for mima-like mound M1 ( $A$ to $L$ ), M2 ( $N$ to $R$ ), M3 ( $S$ to $A B$ ) and the fersiallitic pediment (T). Horizons marked in bold represent the locations where samples were collected to make thin sections. The $\mathrm{pH}_{\mathrm{H} 2 \mathrm{O}}$ was measured in the lab with a $\mathrm{pH}$ meter.

Table 2: Mean percentages, standard errors of the mean (SEM), minimum (min) and maximum ( $\max$ ) clay, silt, and sand contents (relative \%), smectite, and kaolinite contents (relative \%), and ratios of smectite/kaolinite $(\mathrm{S} / \mathrm{K})$ in each cluster and silicate residue of carbonate nodules.

Additional material

Appendix

Table A.1: GPS data of the mima-like mound areas observed with Google Earth (white dots on Fig. 1) 
Figure A.1: Investigated area for the spatial relationship analysis of mima-like mounds according to their distance to their nearest neighbour (Clark and Evans, 1954). Each point (red) represents a mima-like mound $(n=199)$ and is characterized by the observed distance $(r)$ of its nearest neighbour. $A$ is the area, $\rho$ is the density of points in the area, $r_{A}$ is the observed mean distance (Eq. A.1) and $r_{E}$ is the expected mean distance if mima-like mounds were randomly distributed (Eq. A.2). $R$ is the ratio between $r_{A}$ and $r_{E}$ and assesses the degree to which the observed distribution approaches or departs from random distribution. If the spatial distribution is random, then $R=1$, if the aggregation is maximal (where the nearest neighbour distance is 0 ), then $\mathrm{R}=0$, if $\mathrm{R}>1$, then there is an over-dispersion.

$$
\begin{aligned}
& r_{A}=\frac{\sum r}{n} \\
& r_{E}=\frac{1}{2 \sqrt{\rho}}
\end{aligned}
$$


Table 1

\begin{tabular}{|c|c|c|c|c|c|c|c|c|}
\hline $\begin{array}{l}\text { Mima-like } \\
\text { mound }\end{array}$ & Horizons & $\begin{array}{l}\text { Depth } \\
\text { (cm) }\end{array}$ & Structure ${ }^{a}$ & $\begin{array}{l}\text { Skeleton } \\
(\%)^{\mathrm{b}}\end{array}$ & $\begin{array}{c}\text { Skeleton } \\
\text { composition' }\end{array}$ & $\begin{array}{l}\text { Munsell } \\
\text { colour } \\
\text { (moist) }\end{array}$ & $\underset{\% d}{\mathrm{CaCO}_{3}}$ & $\mathrm{pH}_{\mathrm{H} 2 \mathrm{O}}$ \\
\hline \multirow[t]{31}{*}{ M1 } & AH1 & $0-9$ & $S G+A B$ & 0 & - & $2.5 Y 5 / 6$ & $2-10$ & 8.9 \\
\hline & $\mathrm{AH} 2$ & $9-24$ & $A B+M A$ & 1 & Ox / Cnod & $2.5 Y 6 / 4$ & $2-10$ & 8.9 \\
\hline & $\mathrm{AH} 3$ & $24-44$ & $A B+M A$ & 1 & Ox / Cnod & $2.5 Y 6 / 4$ & $0-2$ & 8.8 \\
\hline & $\mathrm{AH} 4$ & $44-59$ & MA & 0 & - & $2.5 Y 5 / 6$ & $0-2$ & 8.9 \\
\hline & $\mathrm{BH} 1$ & $0-5$ & $A S+S G$ & 0 & - & $2.5 Y 5 / 6$ & $2-10$ & 8.6 \\
\hline & $\mathrm{BH} 2$ & $5-24$ & MA & 0 & - & $2.5 Y 5 / 4$ & $10-25$ & 9.0 \\
\hline & $\mathrm{BH} 3$ & $24-64$ & MA & 1 & Cnod & $2.5 Y 6 / 6$ & $?$ & 8.9 \\
\hline & $\mathrm{CH} 1$ & $0-1$ & AS & 1 & Ox & $2.5 Y 5 / 4$ & $>25$ & 8.8 \\
\hline & $\mathrm{CH} 2$ & $1-9$ & $A S+M A$ & $?$ & & $2.5 Y 6 / 4$ & $0-2$ & 8.9 \\
\hline & $\mathrm{CH} 3$ & $9-29$ & MA & 1 & Cnod & $2.5 Y 5 / 4$ & $10-25$ & 9.1 \\
\hline & $\mathrm{CH} 4$ & $29-76$ & MA & 1 & Sil & $2.5 Y 6 / 4$ & $0-2$ & 9.0 \\
\hline & $\mathrm{DH} 1$ & $0-3$ & $A B$ & 1 & Cnod & $2.5 Y 5 / 4$ & $10-25$ & 9.1 \\
\hline & $\mathrm{DH} 2$ & $3-24$ & MA & 1 & Ox/ Cnod & $2.5 Y 5 / 4$ & $0-2$ & 9.1 \\
\hline & $\mathrm{DH} 3$ & $24-60$ & MA & 1 & Cnod & $2.5 Y 5 / 4$ & $0-2$ & 9.1 \\
\hline & DH4 & $60-100$ & $\mathrm{MA}+\mathrm{SG}$ & 1 & Cnod & $2.5 Y 6 / 4$ & $?$ & 8.8 \\
\hline & $\mathrm{EH} 1$ & $0-5$ & AS & 5 & Ox / Cnod & $2.5 Y 4 / 4$ & $>25$ & 8.9 \\
\hline & $\mathrm{EH} 2$ & $5-34$ & MA & 1 & Ox / Cnod & $2.5 Y 6 / 4$ & $0-2$ & 9.1 \\
\hline & $\mathrm{EH} 3$ & $34-114$ & MA & 15 & Ox / Cnod & $2.5 Y 6 / 4$ & $0-2$ & 8.9 \\
\hline & $\mathrm{FH} 1$ & $0-10$ & AS & 3 & Cnod > Ox & $2.5 Y 5 / 4$ & $10-25$ & 8.7 \\
\hline & $\mathrm{FH} 2$ & $10-37$ & MA & 2 & Cnod & $2.5 Y 6 / 3$ & $?$ & 9.1 \\
\hline & FH3 & $37-54$ & MA & 15 & Cnod & $2.5 Y 5 / 4$ & $0-2$ & 9.6 \\
\hline & $\mathrm{FH} 4$ & $54-100$ & MA & 20 & Cnod & $2.5 Y 5 / 4$ & $0-2$ & 9.1 \\
\hline & FH5 & $100-120$ & MA & 5 & Cnod & $2.5 Y 5 / 4$ & $0-2$ & 8.7 \\
\hline & $\mathrm{GH} 1$ & $0-7$ & AS & 2 & Ox & $2.5 Y 6 / 3$ & $10-25$ & 8.6 \\
\hline & GH2 & $7-32$ & MA & 2 & Ox & $2.5 Y 6 / 3$ & $10-25$ & 9.2 \\
\hline & $\mathrm{GH} 3$ & $32-112$ & MA & 15 & Cnod & $2.5 Y 5 / 4$ & $2-10$ & 9.1 \\
\hline & $\mathrm{GH} 4$ & $112-128$ & MA & 1 & Cnod & $2.5 Y 6 / 3$ & $0-2$ & 8.9 \\
\hline & $\mathrm{HH} 1$ & $0-7$ & $A S+M A$ & 2 & Ox & $2.5 Y 5 / 4$ & $10-25$ & 9.1 \\
\hline & $\mathrm{HH} 2$ & $7-96$ & MA & 10 & Cnod & $2.5 Y 5 / 3$ & $2-10$ & 9.2 \\
\hline & $\mathrm{HH} 3$ & $96-120$ & $M A+A S$ & 5 & Cnod & $2.5 Y 5 / 4$ & $0-2$ & 9.0 \\
\hline & $\mathrm{IH} 1$ & $0-20$ & MA & 5 & Ox / Cnod & $2.5 Y 6 / 4$ & $0-2$ & 8.5 \\
\hline
\end{tabular}




\begin{tabular}{|c|c|c|c|c|c|c|c|c|}
\hline & $\mathrm{IH} 2$ & $20-100$ & MA & 0 & - & $2.5 Y 6 / 5$ & 0 & 9.0 \\
\hline & $\mathrm{JH} 1$ & $0-17$ & MA & 0 & - & $2.5 Y 6 / 3$ & 0 & 8.7 \\
\hline & $\mathrm{JH} 2$ & $17-69$ & MA & 1 & Cnod & $2.5 Y 6 / 3$ & 0 & 9.0 \\
\hline & $\mathrm{KH} 1$ & $0-5$ & AS & 1 & Cnod & $2.5 Y 5 / 4$ & $2-10$ & 8.5 \\
\hline & $\mathrm{KH} 2$ & $5-35$ & MA & 0 & - & $2.5 Y 6 / 2$ & 0 & 8.3 \\
\hline & LH1 & $0-35$ & MA & 0 & - & $2.5 Y 6 / 2$ & 0 & 8.5 \\
\hline M2 & $\mathrm{NH} 1$ & $0-8$ & AS & 0 & Cnod & $2.5 Y 6 / 3$ & $0-2$ & 9.3 \\
\hline & $\mathrm{NH} 2$ & $8-41$ & MA & 20 & Cnod & $2.5 Y 6 / 4$ & $0-2$ & 9.5 \\
\hline & $\mathrm{NH3}$ & $41-115$ & MA & 10 & Cnod & nd & $0-2$ & 9.5 \\
\hline & $\mathrm{OH} 1$ & $0-7$ & AS & 5 & Ox / Cnod & $2.5 Y 6 / 4$ & $0-2$ & 9.2 \\
\hline & $\mathrm{OH} 2$ & $7-39$ & MA & 15 & Cnod & $2.5 Y 5 / 3$ & $10-25$ & 9.2 \\
\hline & $\mathrm{OH} 3$ & $39-110$ & MA & 15 & Cnod & 2.5Y5/4 & $0-2$ & 9.4 \\
\hline & $\mathrm{PH} 1$ & $0-13$ & $A B+S G$ & 2 & Cnod & $2.5 Y 6 / 4$ & $>25$ & 8.1 \\
\hline & $\mathrm{PH} 2$ & $13-45$ & SG & 70 & Mix & $2.5 Y 6 / 4$ & $0-2$ & 9.1 \\
\hline & PH3 & $45-100$ & MA & 5 & Ox / Cnod & $2.5 Y 6 / 4$ & $>25$ & 9.2 \\
\hline & QH1 & $0-3$ & $S G+A S$ & 70 & Mix & 10YR4/3 & 0 & 8.0 \\
\hline & QH2 & $3-50$ & SG & 70 & Mix & 10YR4/4 & 0 & 8.1 \\
\hline & QH3 & $50-70$ & MA & 2 & Ox / Cnod & $2.5 Y 6 / 4$ & $0-2$ & 7.9 \\
\hline & QH4 & $70-100$ & MA & 1 & Ox / Cnod & $2.5 Y 6 / 3$ & $2-10$ & 8.5 \\
\hline & $\mathrm{RH} 1$ & $0-2$ & SG & 70 & Mix & 7.5YR3/3 & 0 & 7.5 \\
\hline & RH2 & $2-34$ & SG & 70 & Mix > Sil & 10YR5/6 & 0 & 7.8 \\
\hline & RH3 & $34-67$ & SG & 70 & Mix > Sil & 10YR4/4 & 0 & 8.3 \\
\hline & $\mathrm{RH} 4$ & $67-83$ & AS & 50 & Mix & $2.5 Y 6 / 4$ & $0-2$ & 8.5 \\
\hline & RH5 & 83-95 & MA & 70 & Mix & 2.5Y5/4 & $0-2$ & 8.2 \\
\hline & RH6 & $95-100$ & MA & 2 & Ox / Cnod & $2.5 Y 5 / 4$ & $0-2$ & 8.2 \\
\hline$P$ & TH1 & $0-6$ & SG & 0 & - & 10YR4/6 & 0 & 7.2 \\
\hline & TH2 & $6-21$ & AS & 1 & Sil & 10YR4/4 & 0 & 7.4 \\
\hline & TH3 & $21-42$ & AS & 2 & Sil / Ox & 10YR4/6 & 0 & 7.7 \\
\hline & TH4 & $42-54$ & AS & 3 & $O x$ & 10YR4/6 & 0 & 7.8 \\
\hline & TH5 & 54-105 & MA & 3 & Ox & $2.5 Y 5 / 6$ & $0-2$ & 8.0 \\
\hline M3 & $\mathrm{SH} 1$ & $0-10$ & $S G+A B$ & nd & nd & nd & $10-25$ & 9.3 \\
\hline & $\mathrm{SH} 2$ & $10-70$ & $A B+P R$ & nd & nd & nd & $0-2$ & 9.2 \\
\hline & SH3 & $70-100$ & $A B+M A$ & nd & nd & nd & $2-10$ & 9.3 \\
\hline & $\mathrm{SH} 4$ & $100-120$ & $A B+M A$ & nd & nd & nd & $0-2$ & 9.3 \\
\hline
\end{tabular}




\begin{tabular}{|c|c|c|c|c|c|c|c|}
\hline $\mathrm{UH} 1$ & $0-16$ & $S G+A B$ & nd & nd & nd & $>25$ & 9.2 \\
\hline $\mathrm{UH} 2$ & $16-50$ & $A B+P R$ & nd & nd & nd & $10-25$ & 9.3 \\
\hline UH3 & $50-110$ & $A B+M A$ & nd & nd & nd & $10-25$ & 9.3 \\
\hline WH1 & $0-4$ & $S G+A B$ & nd & nd & nd & $10-25$ & 9.3 \\
\hline WH2 & $4-80$ & $A B+P R$ & nd & nd & nd & $2-10$ & 9.3 \\
\hline WH3 & $80-100$ & $A B+M A$ & nd & nd & nd & $2-10$ & 9.3 \\
\hline $\mathrm{XH} 1$ & $0-10$ & $S G+A B$ & nd & nd & nd & $>25$ & 9.1 \\
\hline $\mathrm{XH} 2$ & $20-40$ & $A B+P R$ & nd & nd & nd & $10-25$ & 9.3 \\
\hline $\mathrm{XH} 3$ & $40-70$ & $A B+M A$ & nd & nd & nd & $10-25$ & 9.4 \\
\hline $\mathrm{YH} 1$ & $0-10$ & $A B$ & nd & nd & nd & $>25$ & 9.3 \\
\hline YH2 & $10-30$ & $A B+P R$ & nd & nd & nd & $2-10$ & 9.4 \\
\hline YH3 & $30-60$ & $A B+P R$ & nd & nd & nd & $10-25$ & 9.4 \\
\hline $\mathrm{ZH} 1$ & $0-20$ & $S G+A B$ & nd & nd & nd & $2-10$ & 9.4 \\
\hline $\mathrm{ZH} 2$ & $20-58$ & $A B+P R$ & nd & nd & nd & $>25$ & 9.4 \\
\hline $\mathrm{ABH} 1$ & $0-14$ & $S G+A B$ & nd & nd & nd & $2-10$ & 9.5 \\
\hline $\mathrm{ABH} 2$ & $15-50$ & $A B+P R$ & nd & nd & nd & $2-10$ & 9.5 \\
\hline
\end{tabular}

a $S G=$ Single grained, $A B=A n g u l a r$ blocky, $A S=A n g u l a r$ and subangular blocky, $M A=$ Massive, $S A B=S u b-a n g u l a r$ blocky, $\mathrm{PR}=$ Prismatic.

${ }^{b}$ soil fraction $>2 \mathrm{~mm}$.

${ }^{c} \mathrm{Ox}=\mathrm{Fe}-\mathrm{Mn}$ oxide, Cnod=carbonate nodule, Sil=silicate, Mix=mixed composition (Ox, Cnod and Sil).

d Carbonate reaction to $\mathrm{HCl} 10 \%$, estimation of carbonate content.

nd=no data 
Table 2

\begin{tabular}{|c|c|c|c|c|c|c|c|c|c|}
\hline & & \multicolumn{5}{|c|}{ Clay-rich sediment } & \multirow{2}{*}{$\begin{array}{l}\text { Alluvium } \\
\text { Cluster } 4\end{array}$} & \multirow{2}{*}{$\begin{array}{c}\text { Fersiallitic pediment } \\
\text { Cluster } 7\end{array}$} & \multirow{2}{*}{ Residue } \\
\hline & & Cluster 1 & Cluster 2 & Cluster 3 & Cluster 5 & Cluster 6 & & & \\
\hline $\mathrm{n}$ & & 18 & 21 & 41 & 52 & 54 & 16 & 5 & 10 \\
\hline \multirow[t]{4}{*}{ Clay (\%) } & Mean & 49.5 & 52.4 & 39.2 & 23.9 & 22.8 & 12.0 & 4.5 & 26.2 \\
\hline & SEM & 2.2 & 2.2 & 1.4 & 1.0 & 1.0 & 1.0 & 0.8 & 2.8 \\
\hline & Min value & 36.7 & 45.5 & 28.1 & 14.0 & 9.1 & 7.6 & 3.3 & 22.1 \\
\hline & Max value & 56.2 & 67.0 & 48.6 & 35.0 & 33.0 & 16.4 & 6.3 & 39.2 \\
\hline \multirow[t]{4}{*}{ Silt (\%) } & Mean & 40.6 & 34.3 & 42.1 & 46.0 & 55.0 & 40.4 & 32.3 & 52.2 \\
\hline & SEM & 1.9 & 1.4 & 1.3 & 0.8 & 1.1 & 3.0 & 3.9 & 3.5 \\
\hline & Min value & 34.5 & 26.0 & 35.3 & 40.2 & 48.0 & 32.3 & 25.7 & 29.3 \\
\hline & Max value & 53.0 & 39.7 & 51.4 & 52.8 & 68.4 & 55.3 & 39.5 & 47.9 \\
\hline \multirow[t]{4}{*}{ Sand (\%) } & Mean & 9.8 & 13.3 & 18.7 & 30.1 & 22.2 & 47.6 & 63.2 & 21.6 \\
\hline & SEM & 0.8 & 1.2 & 1.0 & 1.4 & 0.9 & 6.0 & 10.1 & 3.0 \\
\hline & Min value & 7.1 & 7.1 & 14.2 & 22.1 & 16.0 & 37.1 & 54.2 & 10.6 \\
\hline & Max value & 14.9 & 17.0 & 22.4 & 41.6 & 29.4 & 53.7 & 70.9 & 20.4 \\
\hline $\mathrm{n}$ & & 5 & 5 & 5 & 5 & 5 & 5 & 3 & 12 \\
\hline \multirow[t]{4}{*}{ Smectite (\%) } & Mean & 42.9 & 30.4 & 25.1 & 29.8 & 40.7 & 33.8 & 12.2 & 46.0 \\
\hline & SEM & 8.9 & 3.6 & 2.8 & 7.3 & 2.8 & 4.6 & 0.8 & 4.2 \\
\hline & Min value & 15.8 & 20.2 & 14.1 & 4.5 & 35.0 & 23.8 & 10.2 & 24.1 \\
\hline & Max value & 70.1 & 42.4 & 29.1 & 47.9 & 48.4 & 49.4 & 13.1 & 71.5 \\
\hline \multirow[t]{4}{*}{ Kaolinite (\%) } & Mean & 37.4 & 45.4 & 48.1 & 46.7 & 40.2 & 46.1 & 54.1 & 30.6 \\
\hline & SEM & 4.6 & 1.9 & 1.9 & 4.1 & 2.1 & 2.9 & 3.1 & 2.3 \\
\hline & Min value & 21.4 & 40.5 & 43.1 & 35.5 & 35.9 & 34.9 & 48.9 & 16.2 \\
\hline & Max value & 46.8 & 49.2 & 53.5 & 60.4 & 46.7 & 50.4 & 60.9 & 44.1 \\
\hline \multirow[t]{4}{*}{$\mathbf{S} / \mathbf{K}$} & Mean & 1.4 & 0.7 & 0.5 & 0.7 & 1.0 & 0.8 & 0.2 & 1.8 \\
\hline & SEM & 0.4 & 0.1 & 0.1 & 0.2 & 0.1 & 0.1 & 0.1 & 0.2 \\
\hline & Min value & 0.4 & 0.4 & 0.3 & 0.5 & 0.8 & 0.4 & 0.0 & 0.7 \\
\hline & Max value & 2.9 & 1.0 & 0.6 & 1.3 & 1.3 & 1.2 & 0.3 & 3.8 \\
\hline
\end{tabular}




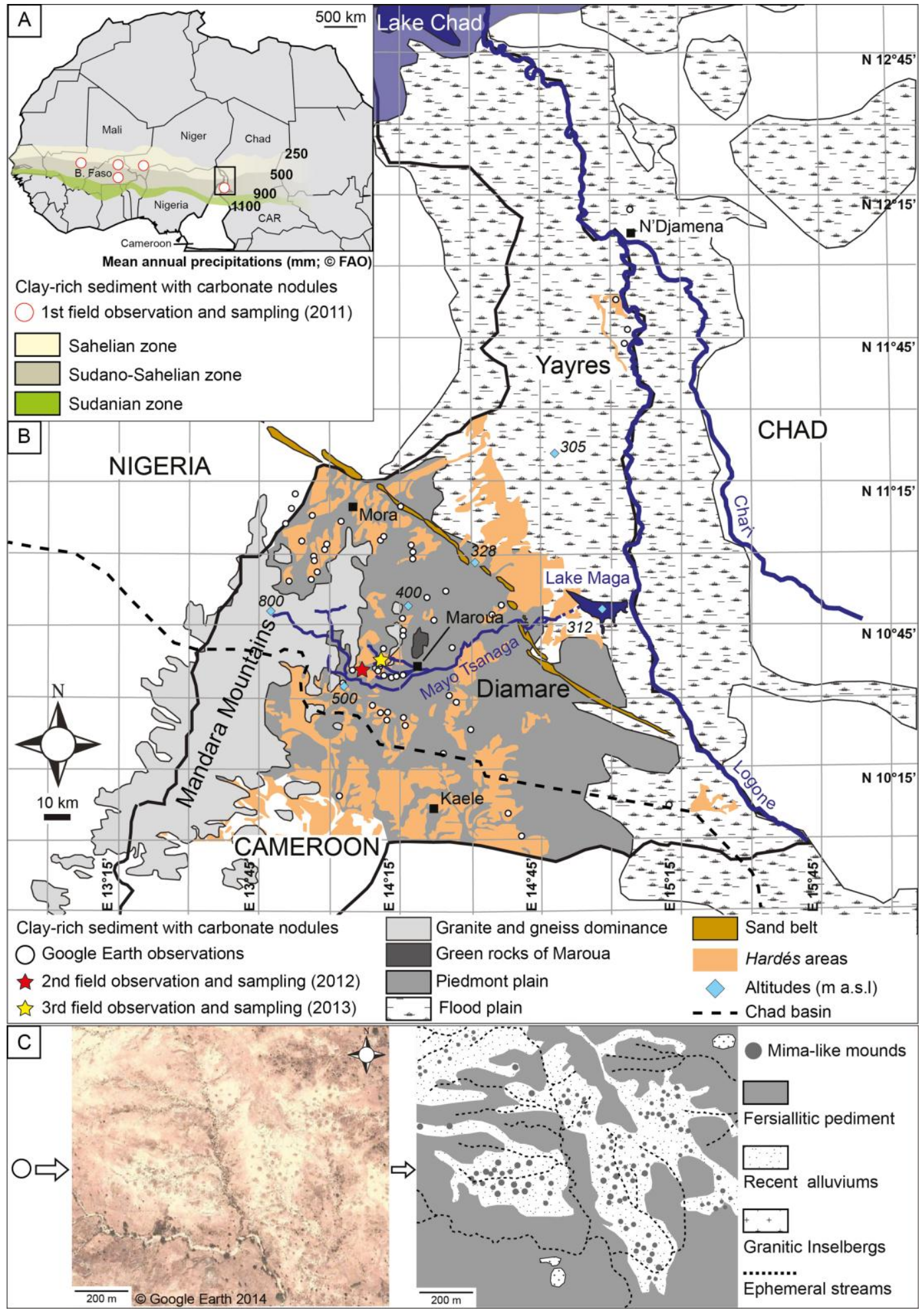




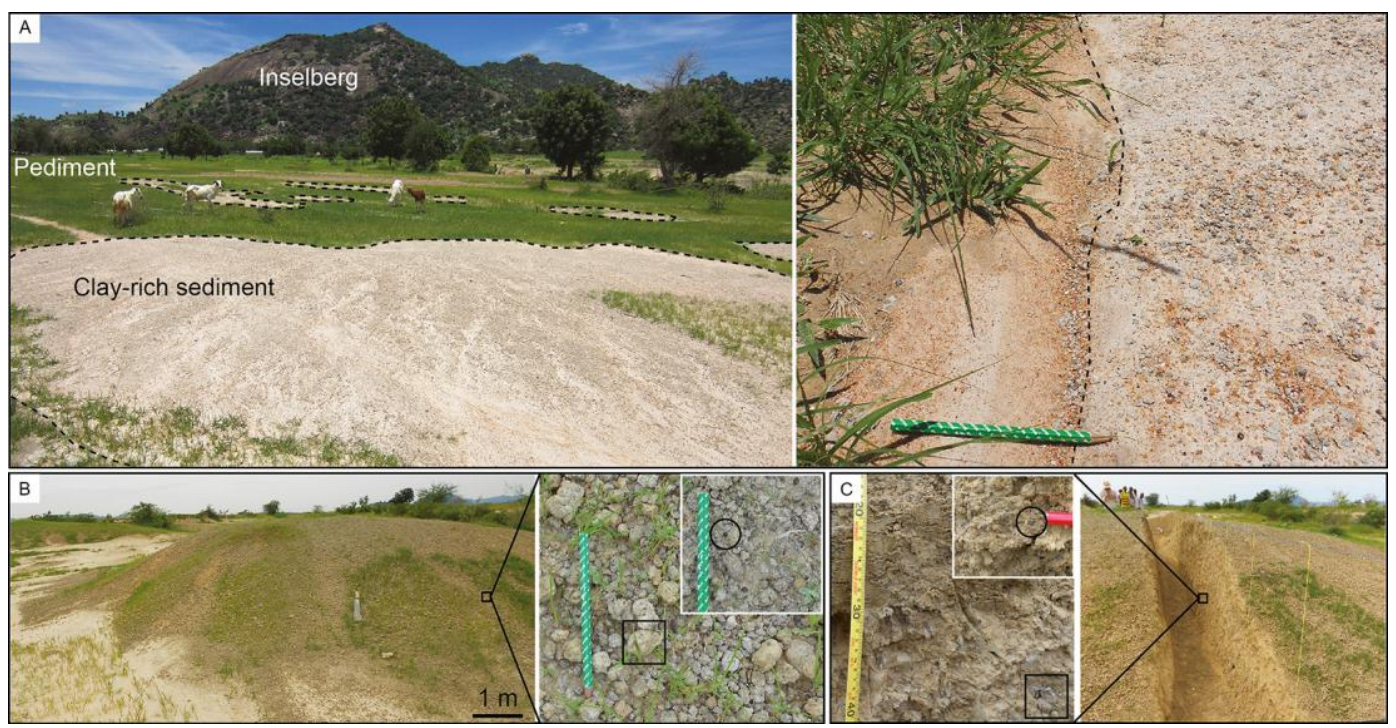




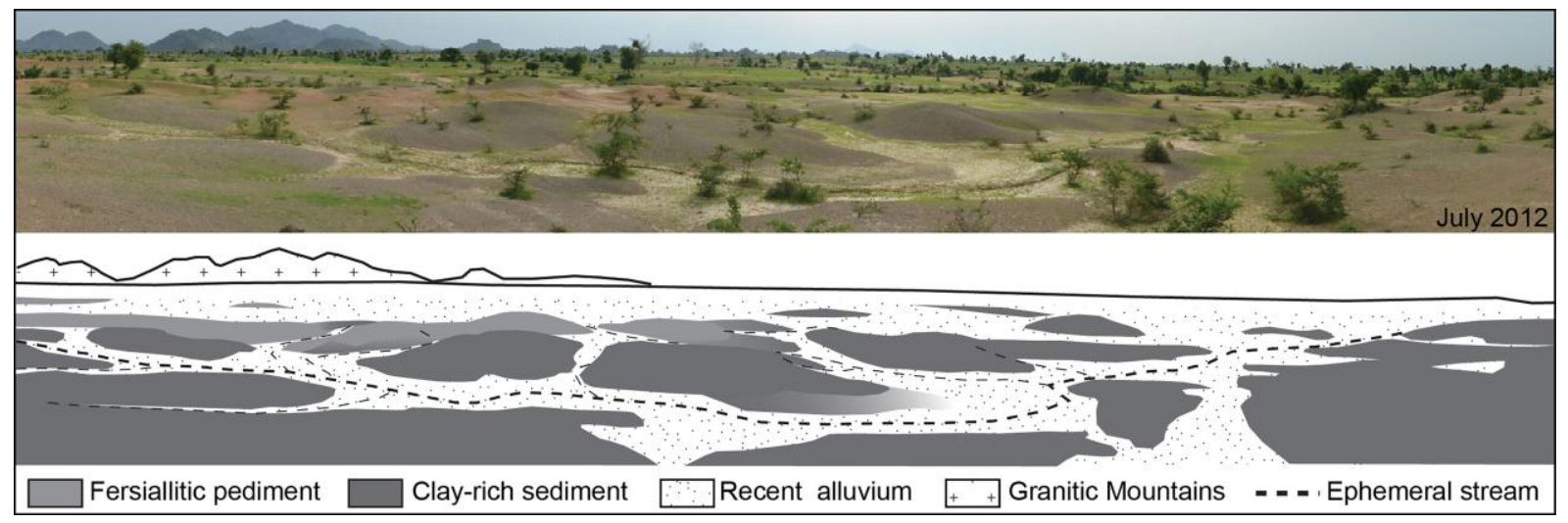




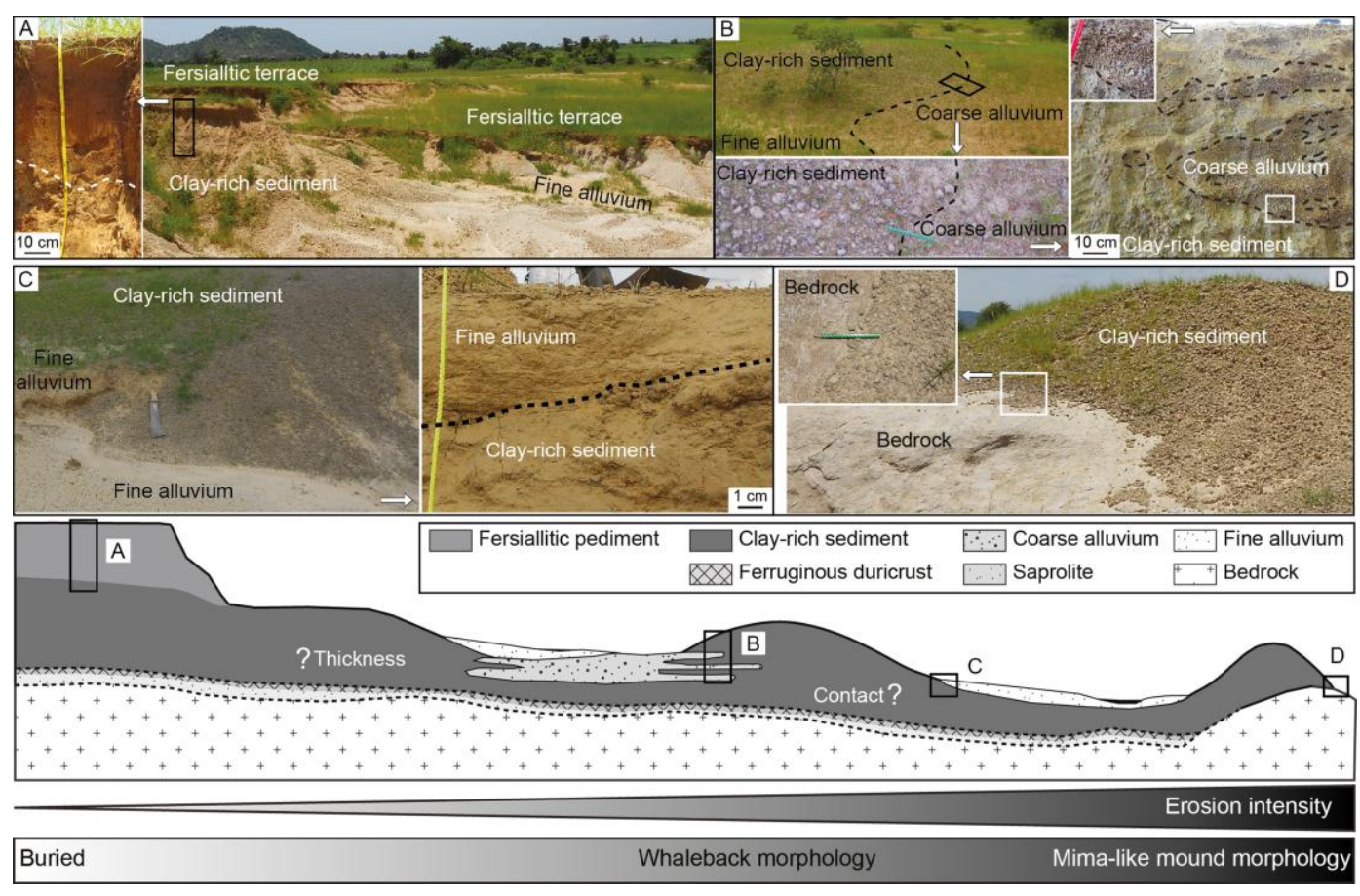




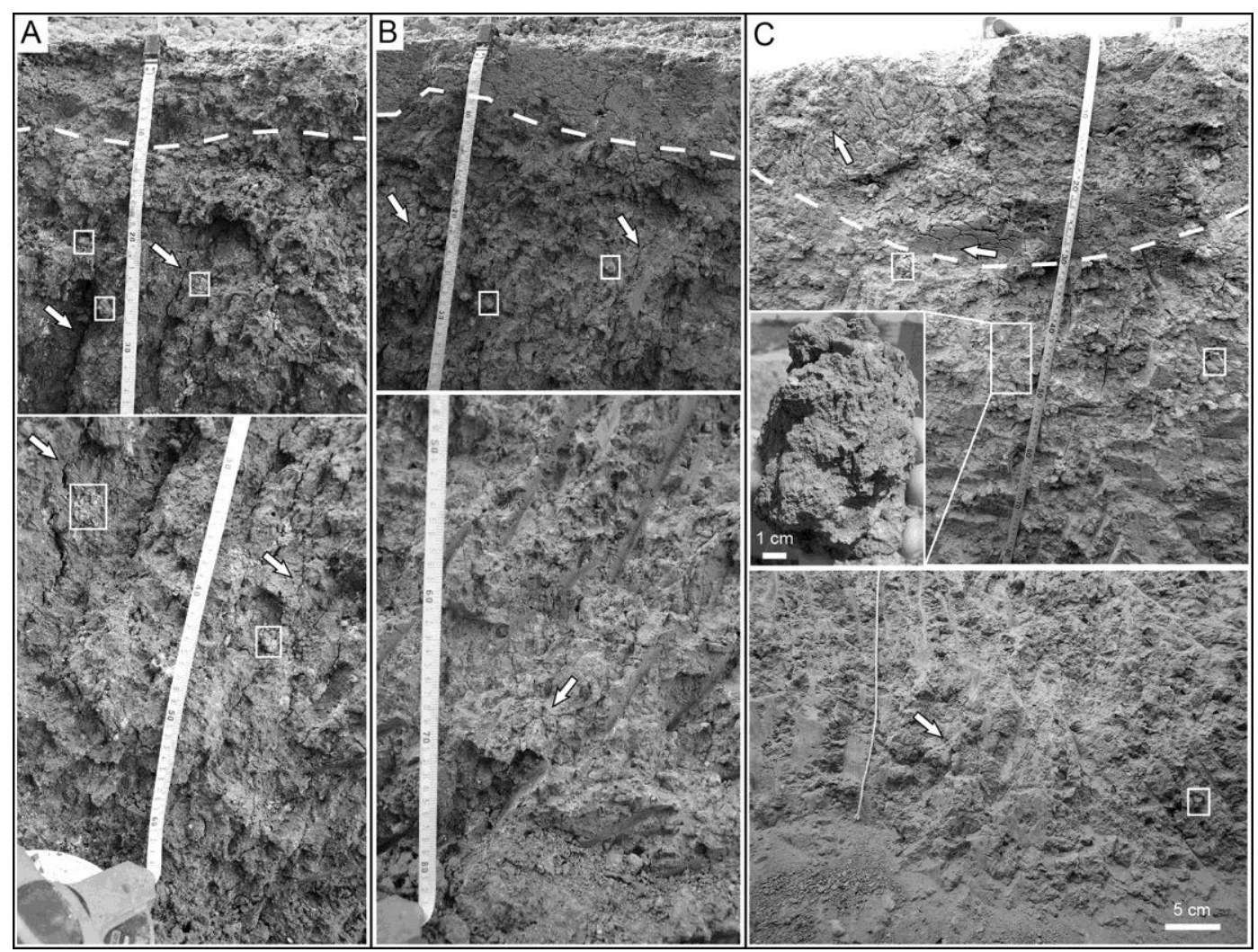




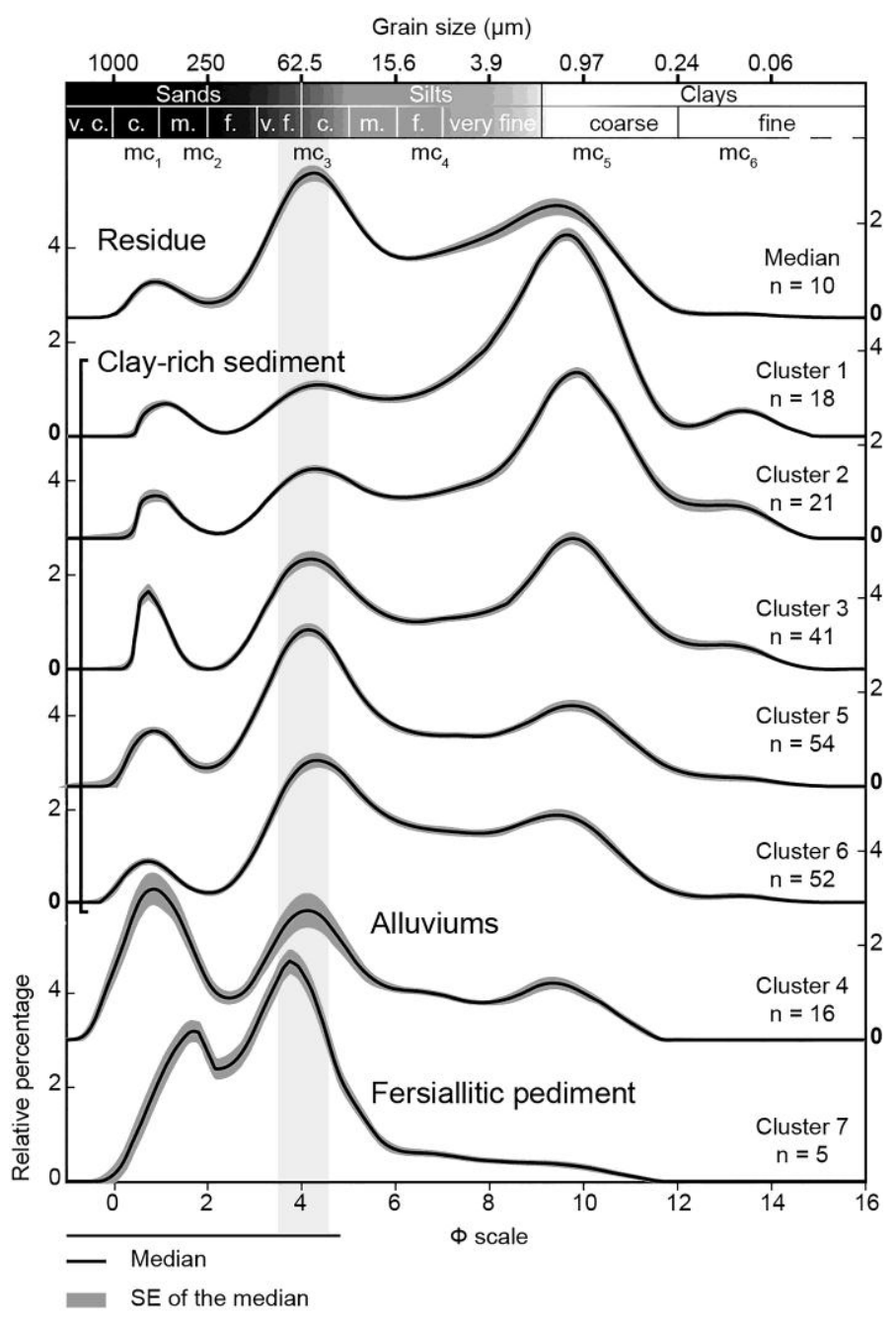




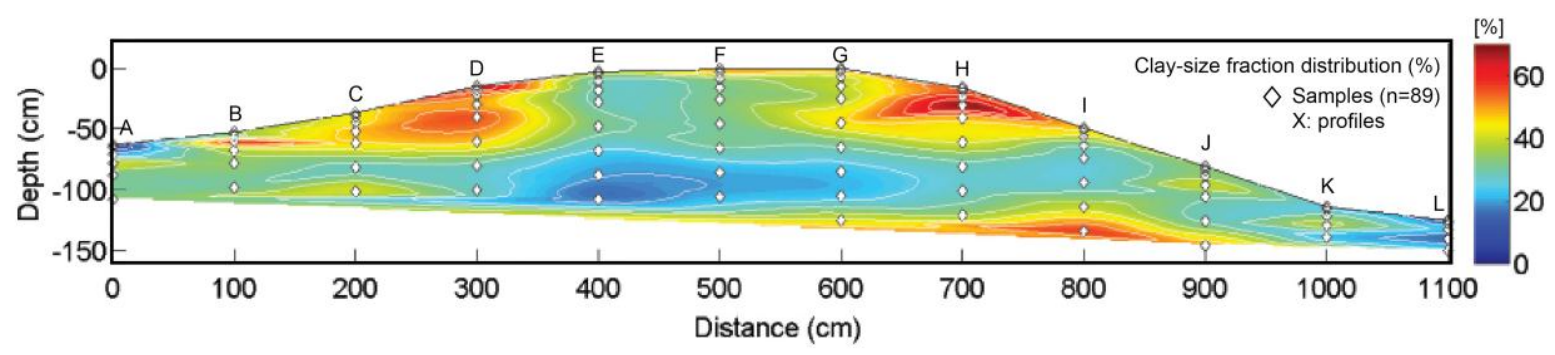



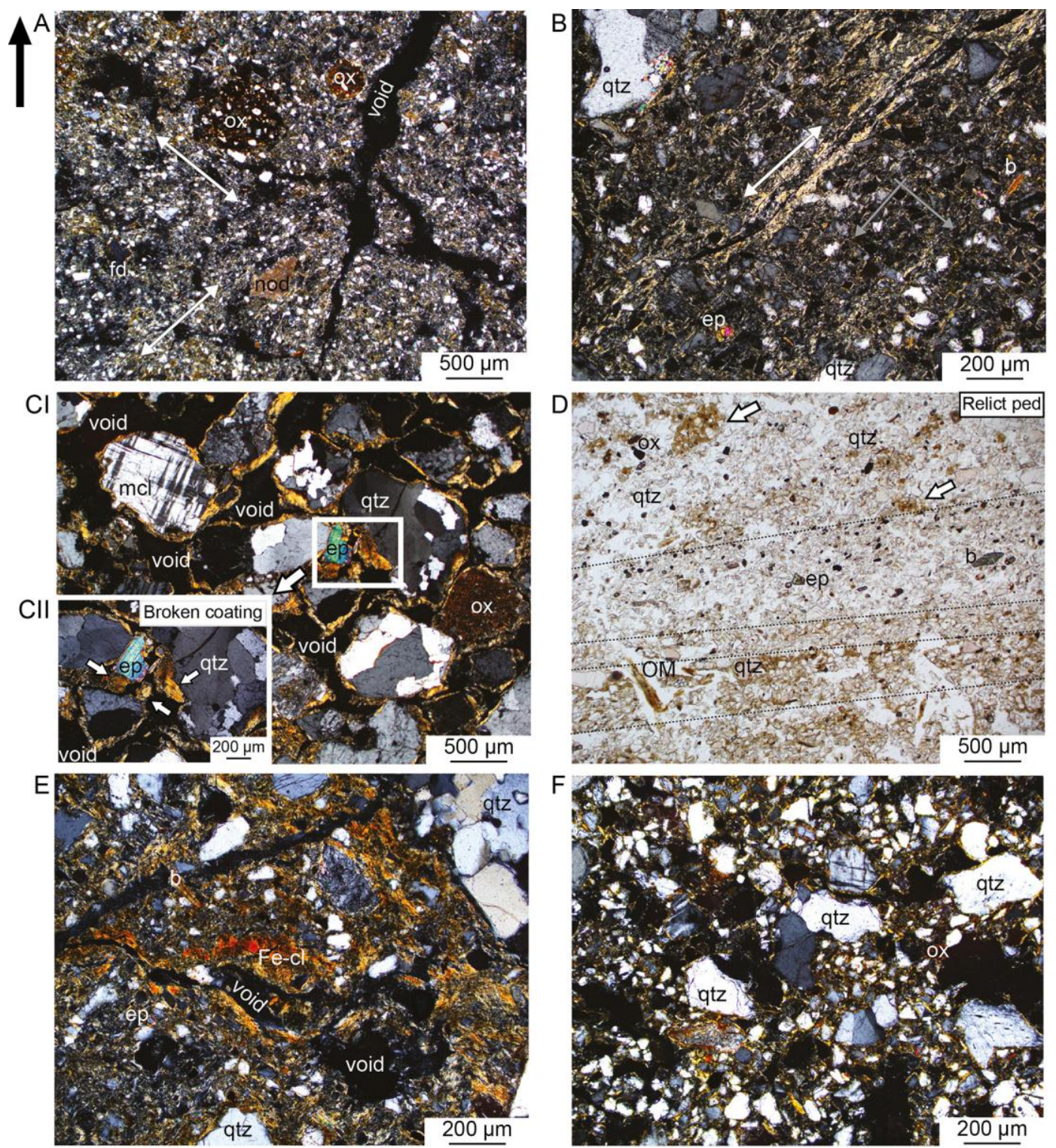


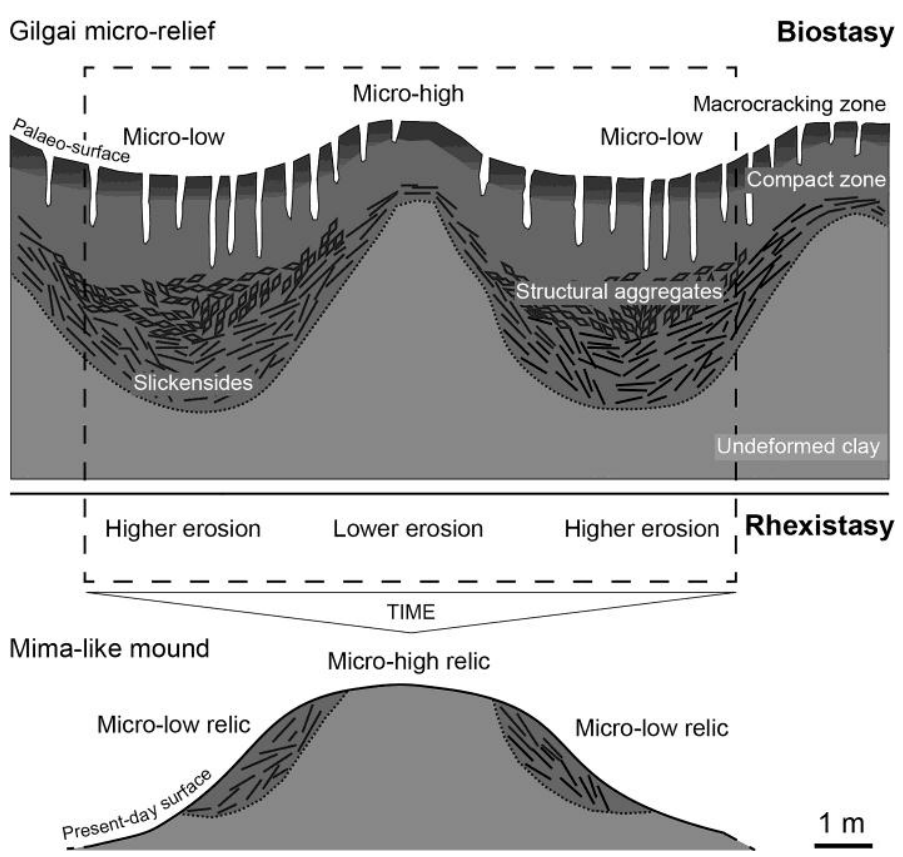

